\title{
Impact of Construction Method and Ground Composition on Headrace Tunnel Stability in the Neelum-Jhelum Hydroelectric Project: A Case Study Review from Pakistan
}

\author{
Hafeezur Rehman ${ }^{1,2}$, Abdul Muntaqim Naji ${ }^{1,3}$, Kyoungmin Nam ${ }^{1}$, Saeed Ahmad ${ }^{4}$, Khan Muhammad ${ }^{5,6(1)}$ \\ and Han-Kyu Yoo ${ }^{1, *}$ \\ 1 Department of Civil and Environmental Engineering, Hanyang University, 55 Hanyangdaehak-ro, \\ Sangnok-gu, Ansan 15588, Korea; miner1239@yahoo.com (H.R.); engineernaji@gmail.com (A.M.N.); \\ namkm@hanyang.ac.kr (K.N.) \\ 2 Department of Mining Engineering, Baluchistan University of Information Technology Engineering and \\ Management Sciences (BUITEMS), Quetta 87300, Pakistan \\ 3 Department of Geological Engineering, Baluchistan University of Information Technology Engineering and \\ Management Sciences (BUITEMS), Quetta 87300, Pakistan \\ 4 Neelum-Jhelum Hydropower Project, Islamabad 44000, Pakistan; saeed_geo17@yahoo.com \\ 5 Department of Mining Engineering, University of Engineering \& Technology, Peshawar 25000, Pakistan; \\ khan.m@uetpeshawar.edu.pk \\ 6 Principal Investigator Intelligent Information Processing Lab, National Centre of AI, University of \\ Engineering \& Technology, Peshawar 25000, Pakistan \\ * Correspondence: hankyu@hanyang.ac.kr; Tel.: +82-31-400-5147; Fax: +82-31-409-4104
}

Citation: Rehman, H.; Naji, A.M.; Nam, K.; Ahmad, S.; Muhammad, K.; Yoo, H.-K. Impact of Construction Method and Ground Composition on Headrace Tunnel Stability in the Neelum-Jhelum Hydroelectric Project: A Case Study Review from Pakistan. Appl. Sci. 2021, 11, 1655. https://doi.org/10.3390/app11041655

Academic Editor: Igal M. Shohet Received: 17 December 2020

Accepted: 8 February 2021

Published: 12 February 2021

Publisher's Note: MDPI stays neutral with regard to jurisdictional claims in published maps and institutional affiliations.

Copyright: (c) 2021 by the authors. Licensee MDPI, Basel, Switzerland. This article is an open access article distributed under the terms and conditions of the Creative Commons Attribution (CC BY) license (https:/ / creativecommons.org/licenses/by/ $4.0 /)$.

\begin{abstract}
During underground construction, the behavior of the ground is influenced by characteristics of the rock mass with situ stresses and ground water, cross section of the excavation area, excavation method, and the rate of excavation. These fundamental features are considered to ensure the support and stability of underground excavations and achieve long-term successful operation. However, the ground composition of the Himalayas hinders tunnel excavation, especially in case of mechanized tunneling; this causes time and cost overruns. This study has reviewed the recently completed Neelum-Jhelum Hydroelectric Project; the project complexities, geological environments involving significant overburden and tectonic stresses, and effects of the excavation method on tunnel stability were analyzed. The major challenges that were encountered during construction are discussed herein along with their countermeasures. An analysis of project-related data reveals that latest techniques and approaches considering rock mechanics were used to complete the project; the existing approaches and methods were accordingly verified and extended. Apart from ground composition, the excavation methods used play an important role in the occurrence of severe rock bursts. Thus, the findings of this study are expected to be helpful for future tunneling projects in the Himalayas.
\end{abstract}

Keywords: empirical classification; ground composition; project-related features

\section{Introduction}

In order to overcome the electricity crisis in Pakistan, the northern part of the country has been considered a suitable location for implementing hydroelectric power projects in the deep dissected valleys, with the aim of achieving large amounts of storage and high water heads for power generation. Underground excavation is a key aspect of almost every hydropower project in this area of the country, owing to the presence of valleys and mountains. However, constructing these hydroelectric power projects in the area is challenging, both technically and financially. From a technical perspective, the Himalaya is a young mountain range; it is tectonically active, and the rocks are reasonably incompetent and affected by a number of faults, folds, and thrusts of varying extents. Moreover, several 
locations in this area also feature with subsurface water. Geological factors, such as the properties of the rock mass, virgin stress settings, and inflow of groundwater through discontinuities, affect the stability of underground excavations and they are called ground composition parameters [1-3]. In the Himalayas, ground composition parameter-related problems, such as rock bursting, squeezing, and groundwater inflow, are encountered in nearly all deep excavation projects [4]. Here, in situ stresses are comparatively unbalanced, as they are geologically age dependent, to a large extent. As it is the youngest mountain chain worldwide, it is relatively more challenging to perform tunneling in this area using tunnel boring machines (TBMs) [5].

Along with ground composition, project-related features, which include the shape and size of the tunnel and the method and rate of excavation, are also important in the successful completion of projects [3]. The underground excavation method (mechanical or drilling and blasting) is responsible for the stress-strain behavior at the excavation face, and this behavior depends on the cross-section of the excavation area, along with the quality of the rock mass [6]. Ground composition parameters are responsible for the risk that is associated with tunneling; therefore, they directly affect excavation-related features of the project [7]. Although mechanical excavation is advantageous in low-stress environments, it is destructive in high-stress environments, as compared to the conventional drill and blast (D\&B) method $[8,9]$.

The Neelum-Jhelum Hydroelectric Project (NJHEP) is a major underground project, constructed in the complex geological environment of the Himalayas, in Pakistan. Almost a decade was required to complete the construction of this project, which can produce $969 \mathrm{MW}$ of electricity. The initial design for underground excavation considered the use of the conventional method; however, during construction, for a significant length of the tunnel excavation, the TBM-based method was used for reducing project construction time. This design altered the project-related features that are associated with challenging ground composition. Underground construction was delayed at different periods, owing to extreme ground compositions, which presented significant challenges during tunneling. The changes in design, quality, and scope of the work resulted in a considerable increase in the construction time and cost [10]. During and after the completion of this project, significant research efforts were devoted toward evaluating the critical role of rock mechanics in the design and construction of underground structures. This study focuses on reviewing the effect of ground compositions and project-related features on tunnel stability that is based on previous research associated with this project.

\section{Project Description \\ General Description}

The NJHEP, undertaken by the Water and Power Development Authority, Pakistan, is a recent hydroelectric project located in northeastern Pakistan, in the Muzaffarabad district of Kashmir, as shown in Figure 1. Its construction commenced in late 2008, and the first turbine generated power in April 2018. The designed capacity of the project is $969 \mathrm{MW}$ of electric power generated from $283 \mathrm{~m}^{3} / \mathrm{s}$ of water; this water is diverted from the Neelum river to the Jhelum river through tunnels, creating a gross hydraulic head of $420 \mathrm{~m}$. The main structures in this project include a diversion dam and an intake system, headrace tunnels, an underground powerhouse complex, and a tailrace tunnel. Underground excavation work accounted for more than $80 \%$ of the construction that was involved in the project. 


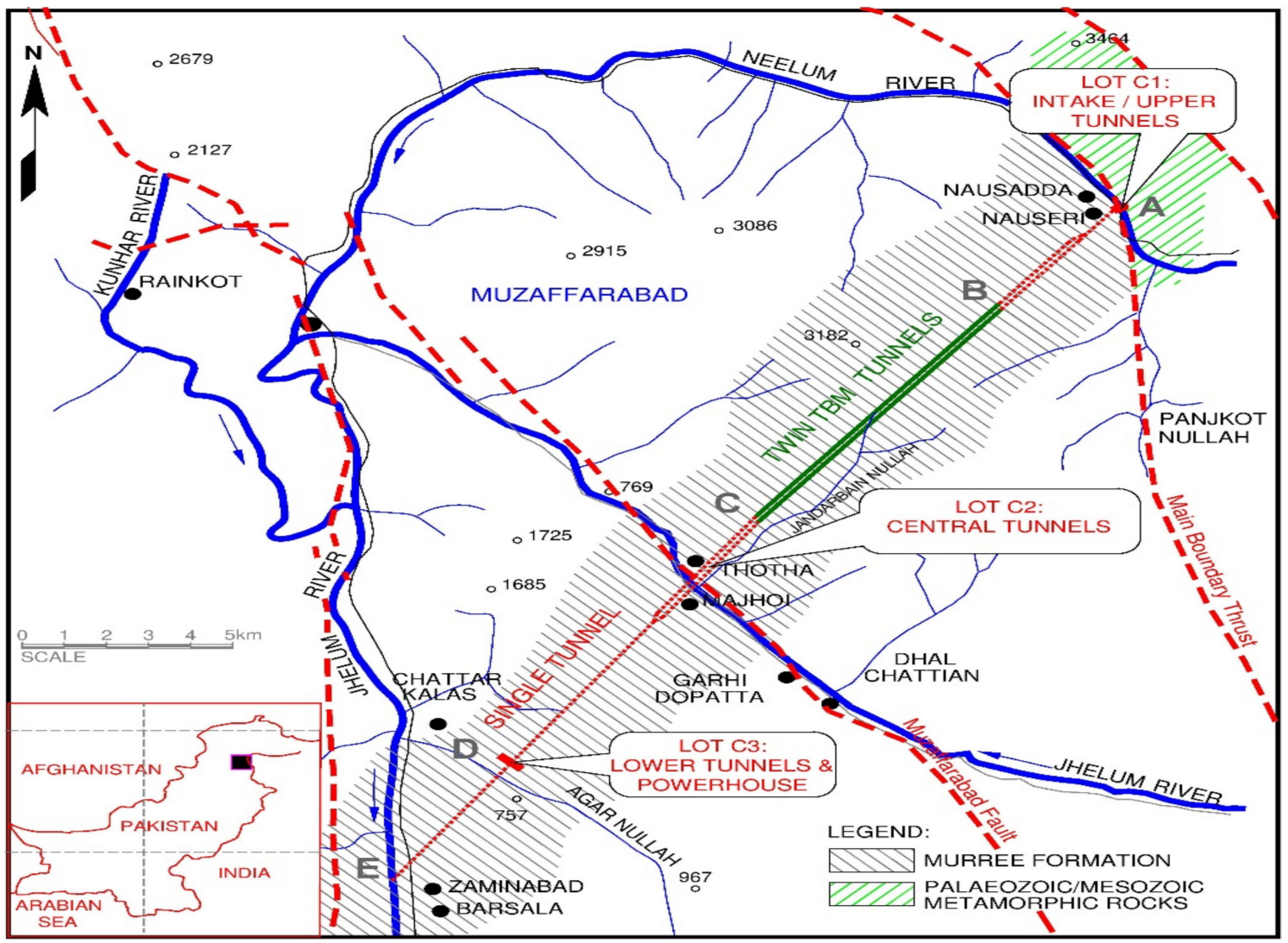

Figure 1. Project location.

The 28.6-km-long headrace tunnels comprise single (34\%) and twin (66\%) circular and horseshoe-shaped tunnels. The tunnels are oriented along the northeast-southwest direction, and the cross-section of the excavation spans ranges of 10.7-11.8 $\mathrm{m}$ and $7.75-8.53 \mathrm{~m}$ for the single and twin headrace tunnels, respectively. A single tunnel with the modified horseshoe-shaped cross-sectional area and a hydraulic span of $9.6 \mathrm{~m}$ is split into twin headrace tunnels ( $0.9 \mathrm{~km}$ from the intake portal). Thereafter, these twin headrace tunnels, with a hydraulic diameter of $6.8 \mathrm{~m}$, rejoin at approximately $20.5 \mathrm{~km}$ downstream from the intake portal. After converging into a single tunnel, the headrace tunnel continues for a distance of $8 \mathrm{~km}$ downstream and it reaches the underground power station comprising four generating units. After generating $969 \mathrm{MW}$ of electric power, a 3.5-km tailrace tunnel discharges the water into the Jhelum river. The project also consists of 10 access adits, with a total length of approximately $11 \mathrm{~km}$.

Commonly unreinforced concrete lining (Type A) with a minimum thickness of $350 \mathrm{~mm}$ was used in this project. Type B linings also have the same minimum thickness; however, they are singly reinforced. In the single tunnel, heavily reinforced Type C structural lining with a thickness of $600 \mathrm{~mm}$ is used. The same type of lining, with a thickness of $500 \mathrm{~mm}$, was used in the twin headrace tunnels. Approximately $44 \%$ of the length of the headrace tunnels is lined with the Type A concrete liner, whereas $42 \%$ (the section mined using the TBM-based method) is lined with shotcrete.

For construction, management, and documentation purposes, the project was divided into three sectors or sites, referred to as Lot C1, Lot C2, and Lot C3 (Figures 1 and 2a). Table 1 lists details of the underground excavation in the project for all three lots. 


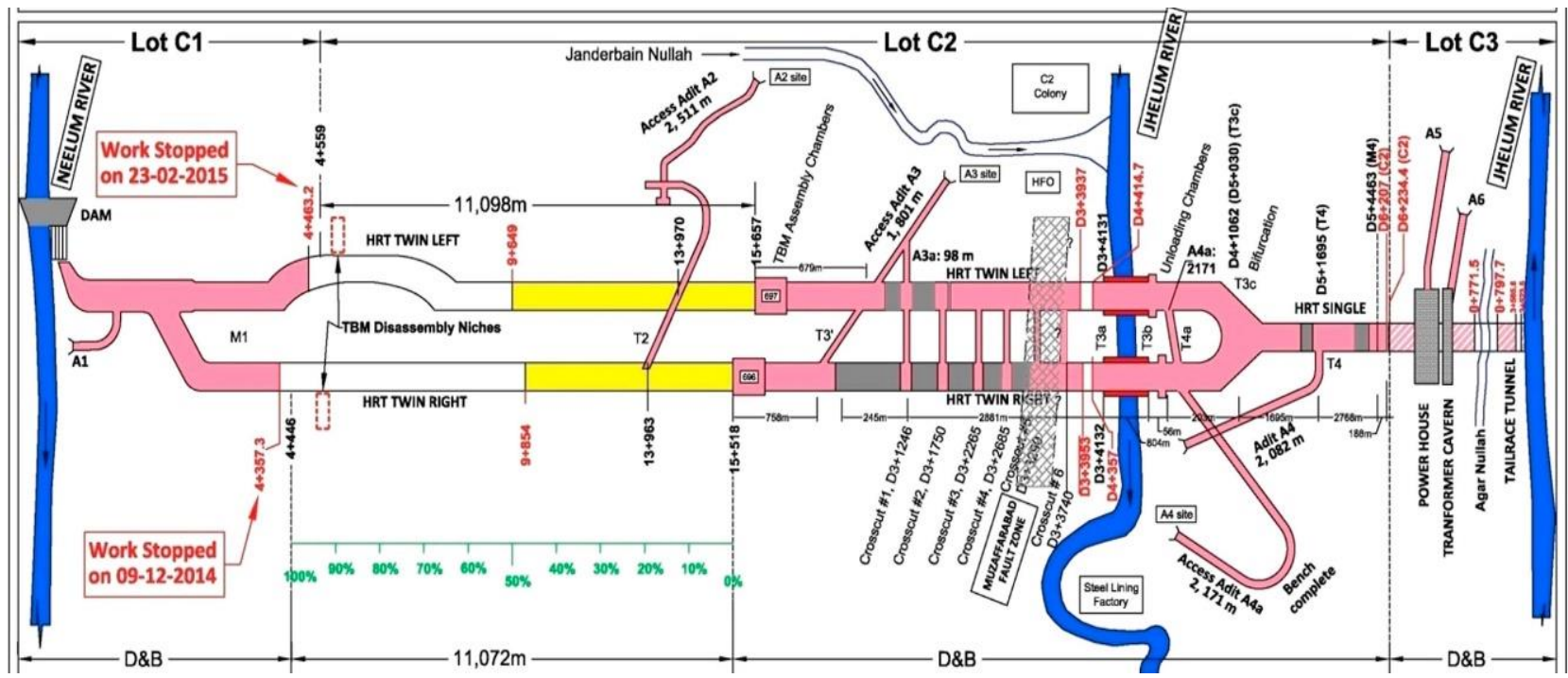

(a)

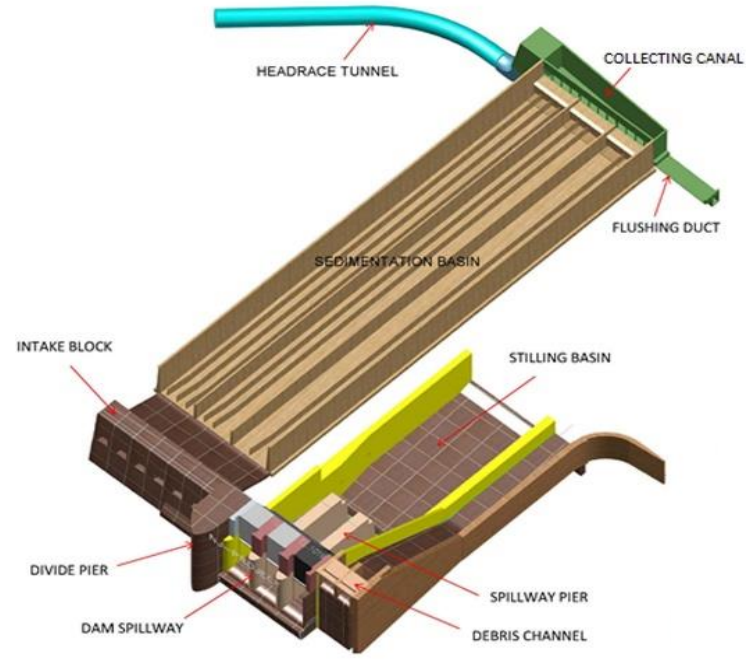

(b)

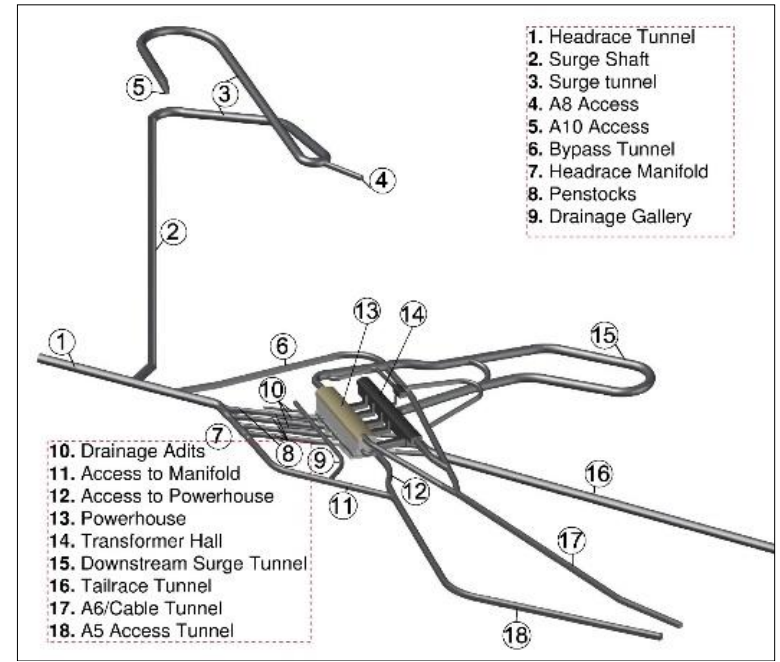

(c)

Figure 2. Cont. 


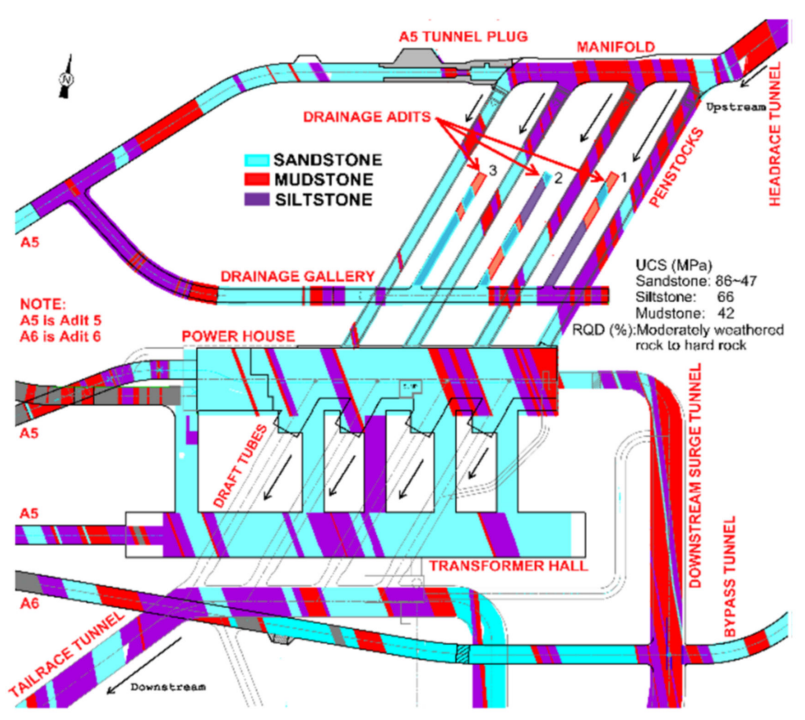

(d)

Figure 2. (a) Project layout showing all three construction sites, (b) dam site, (c) three-dimensional (3D) details of powerhouse, and (d) powerhouse geology and underground construction.

Lot C2 of the project includes the excavation of approximately $43 \mathrm{~km}$ of tunnels, including the access adits. Below the Jhelum river (170-180 m overburden), the 732-m-long twin-tunnel section is called the Jhelum crossing. Steel lining supported this specific length instead of concrete, owing to inappropriate confinement [11]. This section only accounts for $3 \%$ of the total tunnel length. The headrace tunnel features a steep slope of $10.8 \%$ in this stretch, which is upstream of the Jhelum crossing area.

Table 1. Underground excavation details of three lots in the project.

\begin{tabular}{|c|c|c|c|c|c|}
\hline Lot & Excavation & Length (m) & $\begin{array}{c}\text { Excavation Size }(\mathrm{m}) \\
\left(\text { Cross-Sectional Area }\left(\mathrm{m}^{2}\right)\right)\end{array}$ & Shape & Remarks Any \\
\hline \multirow{3}{*}{$\mathrm{C} 1$} & Diversion tunnel & 493 & $10.5 \times 9.5(77)$ & U-shaped & $\mathrm{D} \& \mathrm{~B} *$ \\
\hline & Adit A1 & 390 & $7 \times 8(51)$ & U-shaped & $\mathrm{D} \& \mathrm{~B}$ \\
\hline & $\begin{array}{l}\text { Single headrace } \\
\text { tunnel }\end{array}$ & 874 & $9.7-11.7$ (77-113) & Horse-shoe shaped & $\begin{array}{c}\text { D\&B with finished dia } \\
\text { of } 9.6 \mathrm{~m}\end{array}$ \\
\hline \multirow{9}{*}{$\mathrm{C} 2$} & $\begin{array}{l}\text { Twin headrace } \\
\text { tunnel }\end{array}$ & $4797+4400(\mathrm{R}+\mathrm{L})$ & $7.9(51)$ & Horse-shoe shaped & $\begin{array}{l}\text { D\&B with finished dia } \\
\qquad 6.8 \mathrm{~m}\end{array}$ \\
\hline & $\begin{array}{l}\text { Twin headrace } \\
\text { tunnel }\end{array}$ & $9895+10,434(\mathrm{R}+\mathrm{L})$ & $8.53(57)$ & Circular & $\begin{array}{c}\mathrm{TBM}^{* *} \text { with finished } \\
\text { dia } 7.6-7.9 \mathrm{~m}\end{array}$ \\
\hline & $\begin{array}{c}\text { Twin headrace } \\
\text { tunnel }\end{array}$ & $4950+4837(\mathrm{R}+\mathrm{L})$ & $7.9-8.5(51-60)$ & Horse-shoe shaped & $\begin{array}{l}\text { D\&B with finished dia } \\
\qquad 6.8 \mathrm{~m}\end{array}$ \\
\hline & $\begin{array}{l}\text { Single headrace } \\
\text { tunnel }\end{array}$ & 4433 & $10.7-11(94-100)$ & Horse-shoe shaped & $\begin{array}{l}\text { D\&B with finished dia } \\
\qquad 6 \mathrm{~m}\end{array}$ \\
\hline & Adit A2 & 2475 & $7 \times 8(51)$ & U-shaped & $\mathrm{D} \& \mathrm{~B}$ \\
\hline & Adit A3 & 1890 & $7 \times 8(51)$ & U-shaped & $\mathrm{D} \& \mathrm{~B}$ \\
\hline & Adit A4 & 2090 & $7 \times 8(51)$ & U-shaped & $\mathrm{D} \& \mathrm{~B}$ \\
\hline & Adit A4a & 2175 & $9 \times 9.3(100)$ & Horse-shoe shaped & $\mathrm{D} \& \mathrm{~B}$ \\
\hline & $\begin{array}{l}\text { TBM assembly } \\
\text { chambers }\end{array}$ & $\begin{array}{l}\mathrm{L}=100 \mathrm{~m} \\
\mathrm{R}=60 \mathrm{~m}\end{array}$ & $20 \times 15$ & Horse-shoe shaped & $\mathrm{D} \& \mathrm{~B}$ \\
\hline
\end{tabular}


Table 1. Cont.

\begin{tabular}{|c|c|c|c|c|c|}
\hline Lot & Excavation & Length (m) & $\begin{array}{c}\text { Excavation Size }(\mathrm{m}) \\
\left(\text { Cross-Sectional Area }\left(\mathrm{m}^{2}\right)\right)\end{array}$ & Shape & Remarks Any \\
\hline \multirow{14}{*}{ C3 } & Headrace tunnel & 3622 & 10.7-11.7 (94-113) & Horse-shoe shaped & $\begin{array}{l}\text { D\&B with finished dia } \\
\qquad 6 \mathrm{~m}\end{array}$ \\
\hline & Tailrace tunnel & 3550 & $10.7-11.7$ (94-113) & Horse-shoe shaped & $\begin{array}{l}\text { D\&B with finished dia } \\
\qquad 6 \mathrm{~m}\end{array}$ \\
\hline & Powerhouse & 130 & $23 \times 50$ (varies) & U-shaped & $\mathrm{D} \& \mathrm{~B}$ \\
\hline & $\begin{array}{l}\text { Transformer } \\
\text { cavern }\end{array}$ & 170 & $16 \times 20$ & U-shaped & $D \& B$ \\
\hline & Adit A5 & 660 & $7 \times 8(51)$ & U-shaped & $D \& B$ \\
\hline & $\begin{array}{l}\text { Adit A6 (cable } \\
\text { tunnel) }\end{array}$ & 680 & $7 \times 8(51)$ & U-shaped & $D \& B$ \\
\hline & Adit A7 & 370 & $5 \times 7.5$ & U-shaped & $\mathrm{D} \& \mathrm{~B}$ \\
\hline & Adit A8 & 62 & $6 \times 7$ & U-shaped & $D \& B$ \\
\hline & Adit A10 & 50 & varies & Varies & $D \& B$ \\
\hline & $\begin{array}{l}\text { Surge shaft and } \\
\text { surge tunnel }\end{array}$ & $\begin{array}{l}350 \text { (shaft), } \\
743 \text { (HST) }\end{array}$ & $11,10.7-11.7$ & $\begin{array}{l}\text { Circular shaft and } \\
\text { horse-shoe-shaped } \\
\text { tunnel }\end{array}$ & $\begin{array}{l}\text { D\&B with finished dia } \\
9.6 \mathrm{~m}\end{array}$ \\
\hline & $\begin{array}{l}\text { Drainage gallery } \\
\text { and drainage adits }\end{array}$ & 212,60 & $5 \times 5(\mathrm{DG}), 3 \times 3(\mathrm{DA})$ & U-shaped & $\mathrm{D} \& \mathrm{~B}$ \\
\hline & $\begin{array}{l}\text { Penstocks and } \\
\text { draft tubes }\end{array}$ & $118(\mathrm{P}), 98(\mathrm{D})$ & $6.6 \times 6,6.6 \times 8$ & Varies & $\mathrm{D} \& \mathrm{~B}$ \\
\hline & $\begin{array}{l}\text { Tailrace manifold } \\
\text { and tailrace surge } \\
\text { tunnel }\end{array}$ & 880 & $11.7(113)$ & $\begin{array}{l}\text { Horse-shoe shaped } \\
\text { (varies) }\end{array}$ & $\mathrm{D} \& \mathrm{~B}$ \\
\hline & Bypass tunnel & 300 & $7 \times 8(51)$ & U-shaped & $D \& B$ \\
\hline
\end{tabular}

${ }^{*}(\mathrm{D} \& \mathrm{~B}=$ Drill \& Blast method for excavation $),{ }^{* *}$ (TBM = Tunnel Boring Machine for excavation).

\section{Geological and Geotechnical Conditions of the Area}

\subsection{Regional Geology and Tectonics}

In the Himalayas, the main lithospheric plates, along with microplates, in the region are under constant movement; consequently, the height of the Himalayas is continuously increasing. This movement also activates strike-slip activities along faults away from the collision zone. Because of these activities, the Himalayan region is separated into different litho-tectonic units in terms of extensional and compressional faulting, which range from the northwest to the southeast [12]. These units include the Higher Himalaya, Trans-Himalaya, Sub-Himalaya, Tethyan Himalaya, Lesser Himalaya, and major bounding faults [13]. Figure 3 shows the location of the project, which illustrates that the project was constructed under significantly difficult geological and geotechnical environments between the Hazara-Kashmir Syntaxis (HKS), which is an antiformal structure in the Sub-Himalaya, and it is bounded by two branches of the Main Boundary Thrust (MBT) fault [14,15]. The location of the project shows that two major faults, the MBT and the Muzaffarabad fault (MF), bounded the headrace tunnel, and the axis of the tunnel is sub-perpendicular to the faults (Figure 1). 


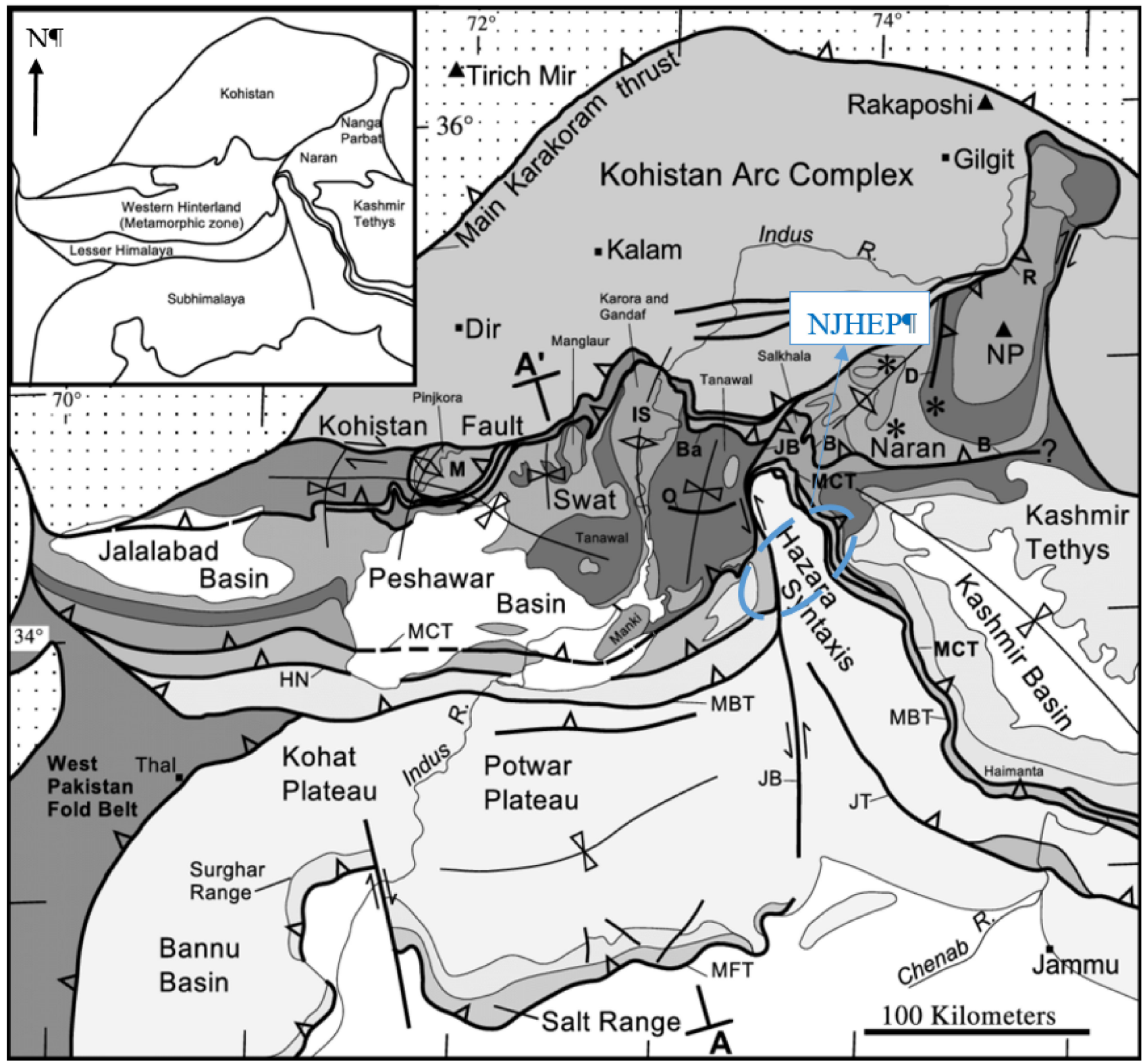

Figure 3. Neelum-Jhelum Hydroelectric Project located in the complex geological environment of the Sub-Himalayan region.

The MBT is one of the major faults in the western part of the Himalayas, with a displacement of approximately $10 \mathrm{~mm}$ per year; moreover, it runs along the entire length of the Himalayan range. This fault separates the younger Sivalik formations (the upper portion of the Sub-Himalayas) and the older formations of the Lesser Himalayas [16]. Performing underground excavations and ensuring their stability under this uncertain environment are challenging tasks for projects using conventional and mechanized tunneling methods, owing to the unexplored in situ geological environment and active tectonics of the region. The seismically active MF was responsible for the disastrous 7.6 magnitude earthquake that occurred on 8 October 2005. More than 87,000 people were killed, and millions were left homeless, owing to this natural disaster. The epicenter of the earthquake was located approximately 30 and $20 \mathrm{~km}$ from the project and Muzaffarabad city, respectively [17].

\subsection{Project Geology Details}

The NJHEP headrace tunnel is the deepest and the underground environment features superior geological settings when compared to global hydropower tunnel projects [18]. The site of the dam is located on the MBT itself, with the abutment on the right composed 
of igneous and metamorphic rocks of the Punjal formation and the abutment on the left composed of the Murree formation (Figure 1). The headrace and tailrace tunnels of the project were excavated in the Murree formation, and the headrace tunnel crosses the Balakot-Bagh reverse fault or Jhelum-Balakot fault, locally called the MF, near the Jhelum crossing, which locally offsets the HKS [19]. The headrace tunnel inlet is at the northeastern limb, while the outlet of the tailrace is at the southwestern limb of the HKS. Along with MF, an unpredicted fault zone was experienced during tunnel excavation, named the Jhelum river fault zone (JRFZ). The size of the MF at the tunnel elevation is nearly $190 \mathrm{~m}$ and it is moderately to intensively fractured. Additionally, the widths of the JRFZ are 60 and $35 \mathrm{~m}$ in the left and right headrace tunnels, respectively. Moreover, this fault was responsible for the rapid water flow into the twin headrace tunnels from the Jhelum river and the occurrence of major collapse incidents below the river bed, owing to which the tunnels were temporarily plugged with concrete $[11,20]$.

Prior to construction, small-scale local faults, along with fault plans, were identified; faults were also encountered during tunneling [21]. Large faults can usually be avoided when designing the projects, but small-scale joints, shear zones, and structural planes are significantly difficult to avoid during the underground construction of the projects [22]. From the investigations, repetitive series of shale and sandstone beds were expected during the feasibility study and detailed design stages of the project. However, during construction, interbedded sandstone and siltstone of the Murree formation, with occasional thin mudstone layers, appeared far more frequently than shale at all three construction sites. The interbedded formation commonly dips steeply with the tunnel axis perpendicular to the strike lines; moreover, the contact among beds is gradational. The fault structures affected this bidding structure, which resulted in a horizontal structure; thus, the steeply dipping structure was converted into a drag fold [23-25].

In the project area, sandstone was further separated into SS1 and SS2 rock units. The first unit is comparatively stronger, contains fine to medium grain, and is well cemented. The fracture density is different in different beds, and the rock mass changes from massive to jointed. The second unit appeared to be steadily changing to form finer materials, including mudstone and siltstone. The sandstone unit (thickness of up to $30 \mathrm{~m}$ ) is relatively massive and competent in high-stress areas. Siltstone is intermixed with mudstone and shale, and its color changes from reddish to grayish brown. Shale and mudstone are the weakest rock beds in the project area with a reddish-brown color, and they are moderately weathered [26]. During tunnel excavation, geological mapping revealed that this weak rock bed had a widely developed sheared zone. The interspace between consecutive shear zones was recorded to be up to $10 \mathrm{~m}$. The saturated $\sigma_{\mathrm{c}}$ (uniaxial compressive strength of intact rock) of mudstone, siltstone, SS2, and SS1 are 24, 65, 102, and 114, respectively [27].

A number of tests were conducted on the rock specimens either in the field or the laboratory during the project design and construction stages. The test results were collected from literature owing to the project length (from the dam site to the powerhouse) and the interbedded geology, and Table 2 presents a detailed summary of the tests. 
Table 2. Properties of rocks in the project area.

\begin{tabular}{|c|c|c|c|c|}
\hline \multirow{2}{*}{ Rock Unit } & \multicolumn{2}{|c|}{ Sandstone } & \multirow{2}{*}{ Siltstone } & \multirow{2}{*}{ Mudstone } \\
\hline & SS1 & SS2 & & \\
\hline \multirow{3}{*}{$\sigma_{\mathrm{i}}(\mathrm{MPa})$} & $\begin{array}{c}86 *[12,18],(138-162)[25] \\
114[27]\end{array}$ & 47 [18], 102 [27] & \multirow{3}{*}{$\begin{array}{c}66 *[12,17,18,28] \\
65[27],(50-70)[29] \\
\quad(20-86.5)[20]\end{array}$} & \multirow{3}{*}{$\begin{array}{c}42 *[12,18,28], 24[27], \\
(30-40)[29],(12-54.1)[20]\end{array}$} \\
\hline & $\begin{array}{r}86 \text { [17], }(50-116)[23], 86.5[2 \\
130-170 \text { and } 23 \% \text { results }> \\
(47-86)[28],(130-230)\end{array}$ & $\begin{array}{l}7 \% \text { test results range } \\
{[30],(120-170)[31],} \\
(20-114.6)[20]\end{array}$ & & \\
\hline & $(100$, & $30,75,60,50,45,40)[3$ & & \\
\hline \multirow{2}{*}{$\mathrm{E}_{\mathrm{i}}(\mathrm{GPa})$} & $\begin{array}{l}58.1 *[12], 32[18] \\
(42.5-62.8)[25]\end{array}$ & 18.8 [18] & \multirow{2}{*}{$\begin{array}{c}40.6 \text { * }[12,17], 23.1[18], \\
21[20]\end{array}$} & $27.4 *[12], 12.6[18]$ \\
\hline & 34 [24], 58.1 [17], 32 & $20^{* * * *}[22,31]$ & & $12.6[20]$ \\
\hline \multirow{2}{*}{$\sigma_{t}(\mathrm{MPa})$} & $7.72 *[12,18]$ & $8.51[18]$ & \multirow{2}{*}{$\begin{array}{c}6.93 *[12,17,18] \\
\quad(4.7-6.8)[20]\end{array}$} & \multirow{2}{*}{$\begin{array}{c}5.24 *[12] \\
(5.2-8.2)[20]\end{array}$} \\
\hline & $(3.9-11.0$ & & & \\
\hline \multirow{2}{*}{ GSI } & $65[12,18]$ & $50[18]$ & \multirow{2}{*}{$50[12,18]$} & \multirow{2}{*}{$50[12,18]$} \\
\hline & $63[2$ & & & \\
\hline \multirow{2}{*}{$v$} & $0.27 *[12], 0.25[18]$ & - & \multirow{2}{*}{$0.3[17], 0.22$ [20] } & \multirow{2}{*}{$0.21 *[12], 0.26[20]$} \\
\hline & $0.27[17,20], 0.2$ & $*[22,31]$ & & \\
\hline \multirow[t]{2}{*}{ c (MPa) } & $\begin{array}{c}6.02 *[12],(4.9 \text { and } 3.6) * * \\
{[18]}\end{array}$ & - & \multirow[t]{2}{*}{$8.91 *[12,17]$} & \multirow[t]{2}{*}{$5.87 *[12]$} \\
\hline & $4.2^{* * * *}[$ & & & \\
\hline \multirow[t]{2}{*}{$\Phi\left(^{\circ}\right)$} & $\begin{array}{c}45.98 *[12],(0 \text { and } 46) * * * \\
{[18]}\end{array}$ & - & \multirow[t]{2}{*}{$54.31 *[12,17]$} & \multirow[t]{2}{*}{$33.33 *[12]$} \\
\hline & $47.8[17], 42$ * & $2,31]$ & & \\
\hline \multirow{2}{*}{ Specific gravity } & $2.73 *[12]$ & - & $2.8 *[12]$ & $2.7 *[12]$ \\
\hline & 2.73[ & & $2.77[20]$ & $2.72[20]$ \\
\hline \multirow{2}{*}{$\mathrm{m}_{\mathrm{i}}$} & 17 [12] & - & \multirow{2}{*}{$7[12]$} & \multirow{2}{*}{9 [12] } \\
\hline & $15[2$ & & & \\
\hline
\end{tabular}

${ }^{*}=$ average values; $^{* *}=$ cohesion (peak and residual) ${ }^{* * *}=$ friction angle (peak and residual); ${ }^{* * *}=$ rock mass property.

\section{In-Situ Stresses}

\subsection{General}

The Himalayan area is known to be the most tectonically active range worldwide, owing to the collision of two tectonic plates, i.e., the Eurasian and Indian plates. This range has a complex geological history due to the Indian plate displacement of $20-50 \mathrm{~mm} /$ year along the Himalaya frontal fault. This fault is responsible for various disastrous earthquakes, including the aforementioned earthquake that occurred in 2005 [33-35]. Apart from earthquakes, these movements are the major cause of high horizontal stresses in the area. The stress magnitude fluctuations in the area are related to the in situ rock-mass properties, along with the geographic location, as well as the distance from the fault. The horizontal stress $\left(\sigma_{h}\right)$ in the area can be obtained, as follows [1]:

$$
\sigma_{h}=\frac{v}{1-v} \times \sigma_{v}+\sigma_{t e c}
$$

where $v, \sigma_{v}$, and $\sigma_{t e c}$ are the Poisson's ratio, the gravity stress, and tectonic horizontal stress (locked-in stress), respectively.

The underground stress environment can be determined based on six independent parameters: the magnitude and direction of principal stresses $\left(\mathrm{S}_{\mathrm{H}}, \mathrm{S}_{\mathrm{h}}\right.$, and $\mathrm{S}_{\mathrm{V}}$ or $\sigma_{1}, \sigma_{2}$, 
and $\sigma_{3}$ ). The in situ test campaigns were conducted at different stages of the project for determining the actual stress conditions and orientation.

\subsection{Results of Stress Determination}

The World Stress Map reveals the thrust faulting situation in the area; moreover, the horizontal stresses that are due to the tectonic stress are oriented along the N60-65E direction, as shown in Figure 4. In this project, in situ stresses were determined via hydrofracturing and hydro-jacking at two critical sites: (1) the Jhelum river crossing and (2) the underground powerhouse. The test results varied, owing to the anisotropic nature of rock and high in situ stresses [30]. Subsequently, an overcoring stress measurement method, with hollow inclusion triaxial strain cells, was used for stress determination in the high overburden area along the TBM-excavated tunnels of the project, which were susceptible to rock bursting. The China Institute of Rock and Soil Mechanics executed these tests [36]. Fifteen boreholes were drilled in the periphery of the twin headrace tunnels and the testing locations were positioned sufficiently far away from the periphery of the tunnel for safeguarding against construction disturbance. In a high in situ stress environment, core discing occurred in several tests, and only a few tests were completed successfully [24]. Based on the test results in the high-stress environment, it is presumed that the stress levels are higher in the borehole with core disking than in the successfully completed test bore holes [37]. The test details were collected and summarized from published literature, as listed in Table 3.

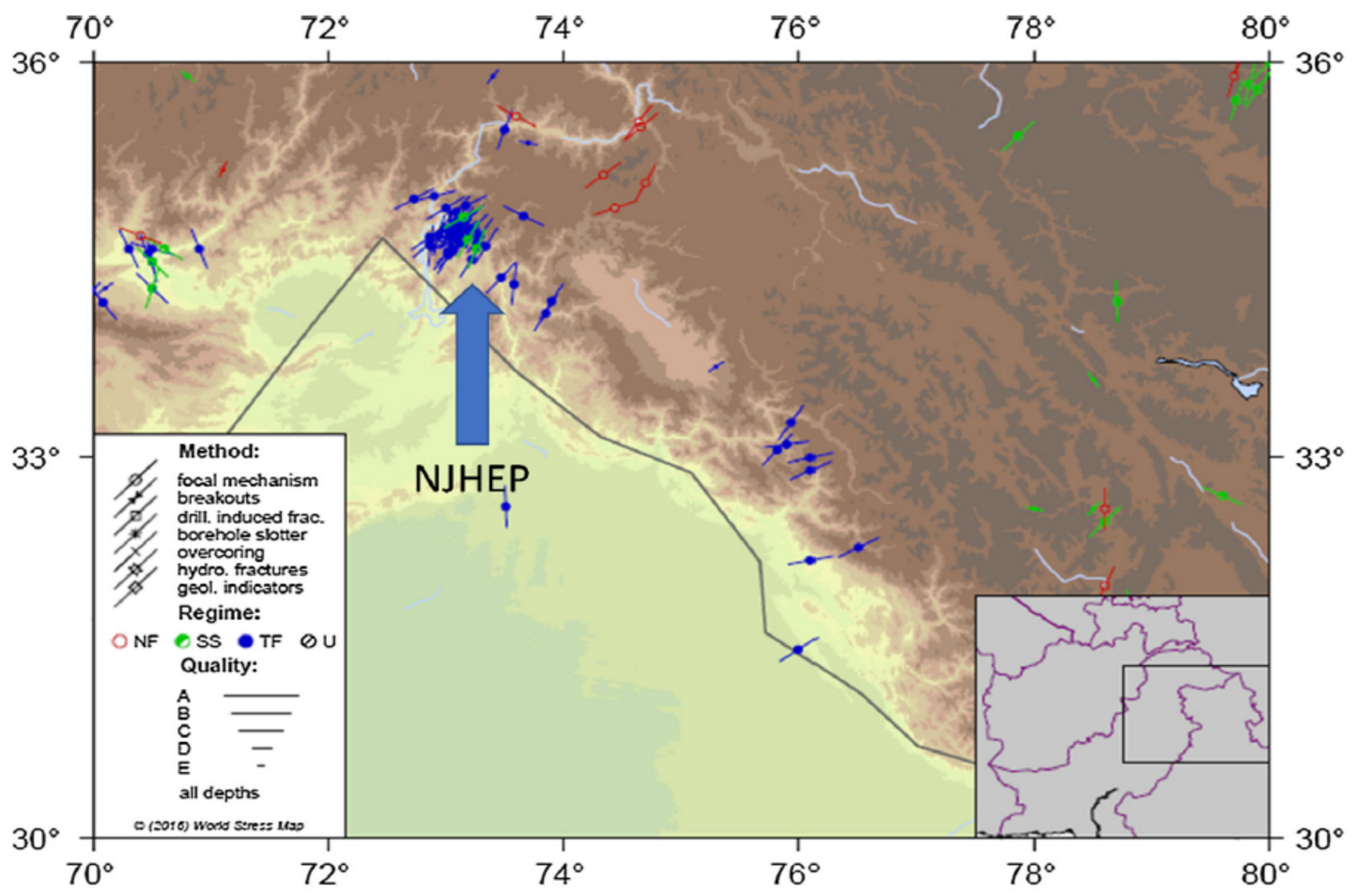

Figure 4. Stress conditions in the project area, obtained using the World Stress Map. 
Table 3. Results of in situ stresses from overcoring (measured in tunnel boring machine-excavated headrace tunnel sections).

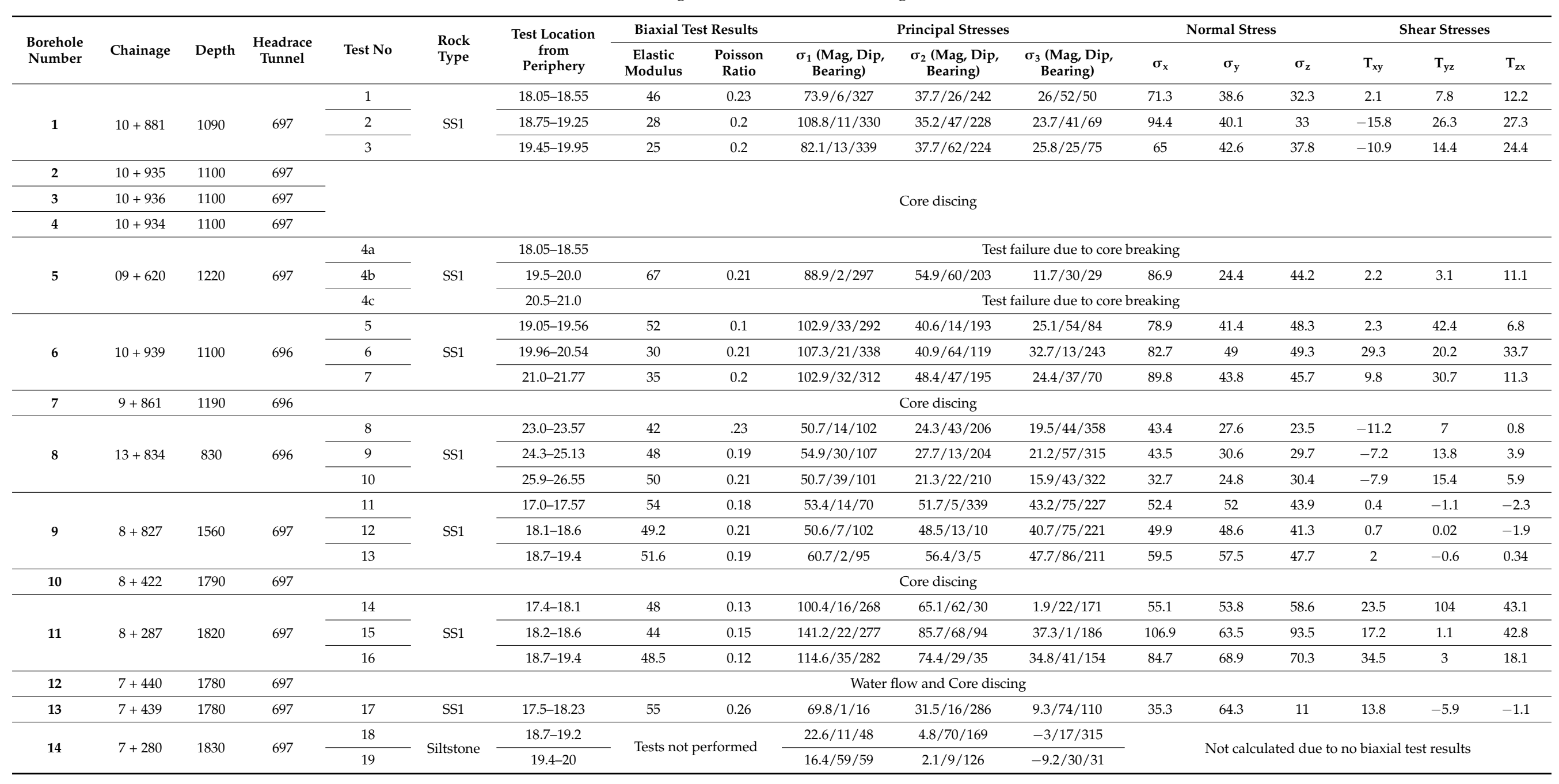


The in situ stress results are plotted at the tested chainage of the tunnel in terms of $\mathrm{K}_{0}$ (ratio of horizontal to vertical stress) and the overburden (Figure 5). The results indicate the higher horizontal stresses due to tectonics along the tunnel route with a higher $\mathrm{K}_{0}$ value [37,38]. The horizontal stress $\left(\sigma_{1}\right)$ is greater than $100 \mathrm{MPa}$, as observed from Table 3 . Higher values of $\sigma_{1}$ are not completely dependent on the tunnel depth as they are perpendicular to the longitudinal axis of the tunnel when the overburden values range from 800 to $1000 \mathrm{~m}$ (as shown in Figure 5). The horizontal stress is lower in the area with maximum overburden heights. $\sigma_{1}$ and $\sigma_{2}$ are perpendicular and parallel to the tunnel axis in the horizontal plane, respectively; further, $\sigma_{3}$ is in the vertical direction. Based on the field testing program, a similar stress trend was also noted in the nearby Kohala hydropower project that was being designed [35]. However, in the powerhouse area, $\sigma_{1}$ is vertical with a value of $12 \mathrm{MPa}$, and the magnitudes of the intermediate and minor principal stresses are 5 and $3 \mathrm{MPa}$, respectively [28].

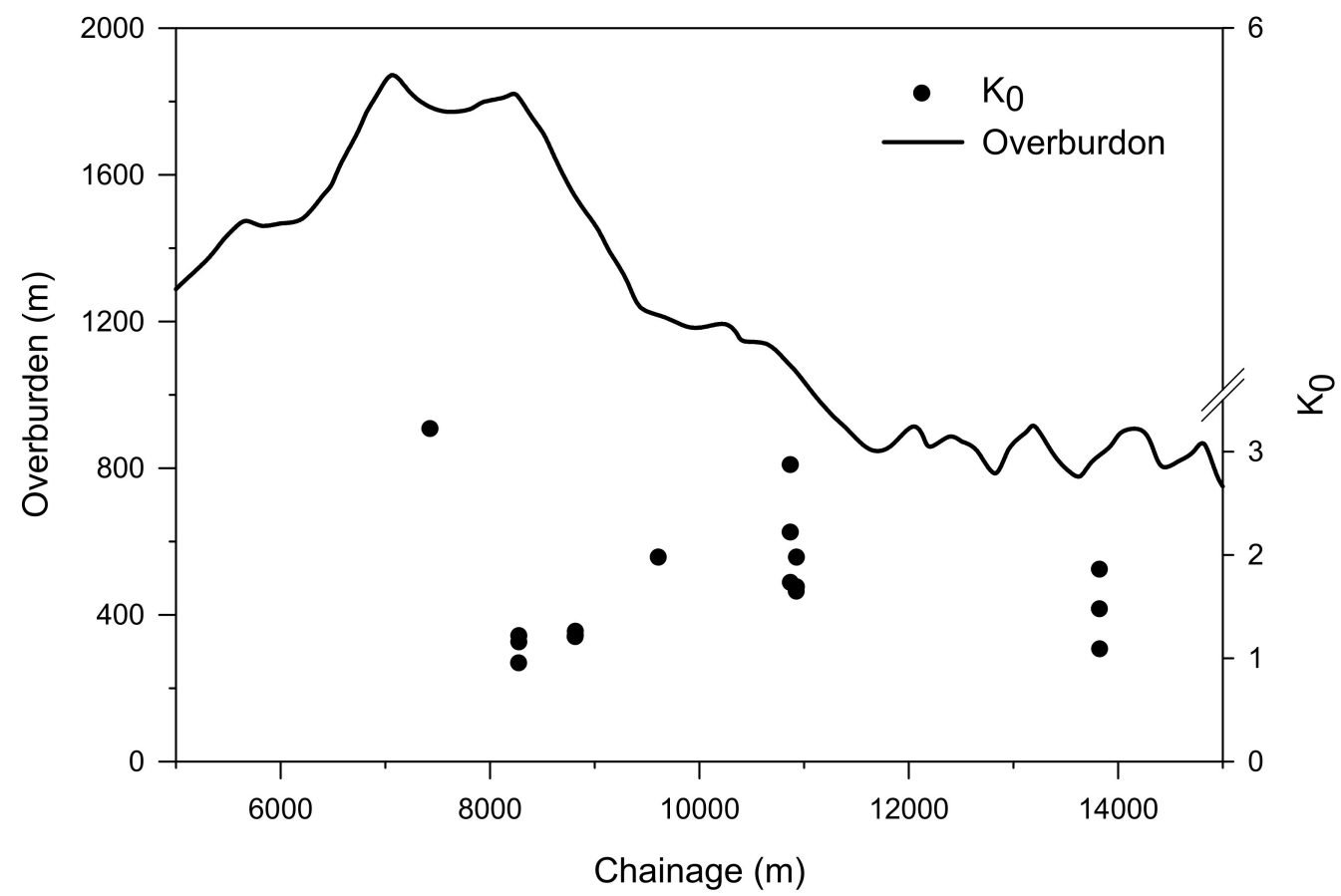

Figure 5. In situ stress state along headrace tunnels in sever rock burst zone.

\section{Tunnel Excavation}

\subsection{General}

The two general types of rock tunneling methods are as follows: (1) the mechanical method and (2) the drill and blast/conventional excavation method. The foremost dissimilarities between them are associated with tunnel excavation, support cycle, and work continuity during construction. The selection of the excavation method depends on the ground composition and project-related features, and the choice of the method directly affects project costs.

The excavation methods were evaluated for their application to the NJHEP, and no key stability problems were identified while using the conventional and roadheader-based excavation methods, other than their low excavation advance rate as compared to the TBM-based method [39]. The utilization of TBMs in the Himalayas is not promising, because of the occurrence of folds, faults, shear zones, mixed geology, high in situ stresses, water charged formations, etc. [40]. However, developments are being considered to solve the existing issues and enable TBM-based tunneling to be an effective approach in the Himalayas, owing to the advanced features in the TBM. 


\subsection{Drill and Blast Excavation}

In all three lots of the project, the conventional excavation method was used for underground excavation. The single tunnel, along with the powerhouse cavern, transformer hall, TBM assembly chamber, and all adits and sections of the twin tunnels, were completed using drill and blast methods (refer to Table 1). From the multiple access adits, excavation was conducted along two opposite directions (upstream and downstream). The top heading and benching excavation sequence was adopted for the single headrace tunnel, whereas full-face excavation was used for the twin tunnels. The top heading and benching method is a typical excavation approach that is used for large-sized rock tunnel excavations [41]. Assembly chambers for the TBMs, an underground powerhouse, and a transformer hall were constructed using the multiple drift method, while considering the special cross-sectional sizes of these structures and poor rock mass quality.

\subsection{Tunnel Boring Machine Excavation}

In the area with a high overburden, the conventional excavation method for the headrace tunnel was replaced, in order to expedite the excavation and construction of the project, for approximately $20 \mathrm{~km}$ in Lot C2. However, the lack of foresight regarding geological problems was disastrous for TBM-based tunneling at this stage of the project owing to the high overburden. Two rock behaviors were scrutinized under the high-stress environment along the longitudinal section of the headrace tunnel, i.e., (1) competent brittle rock (rock burst) and (2) weak rock (squeezing).

In the planning stage of tunneling using TBMs for excavation, the primary issues were the squeezing probability of up to $500 \mathrm{~mm}$, as was indicated for the weak rock mass, and rock bursting in brittle rock under a high-stress environment. Similar concerns were also encountered during the construction of the Gotthard Base Tunnel, where the project was successfully finalized using open (gripper) TBMs [42]. Similar machines were chosen for this project, which was suited for the aforementioned possible behaviors. The two TBMs, named TBM 697 and TBM 696, excavated a considerable portion of the twin headrace tunnels, and they ascended from the southwest to northeast directions at a slope of $0.8 \%$ upstream. The two tunnels were designed in parallel with a modified separation distance of $55 \mathrm{~m}$, which was originally $33 \mathrm{~m}[17,25]$. The purpose of this modification was to reduce the induced stress in the inter-tunnel pillar. For both of the TBMs, the support installation equipment facilities were present at location L1. This section was $6 \mathrm{~m}$ behind the cutter head shield, as shown in Figure 6. Section L2 was $60 \mathrm{~m}$ after section L1 and it featured an additional facility for shotcrete spray robots and rock bolting.

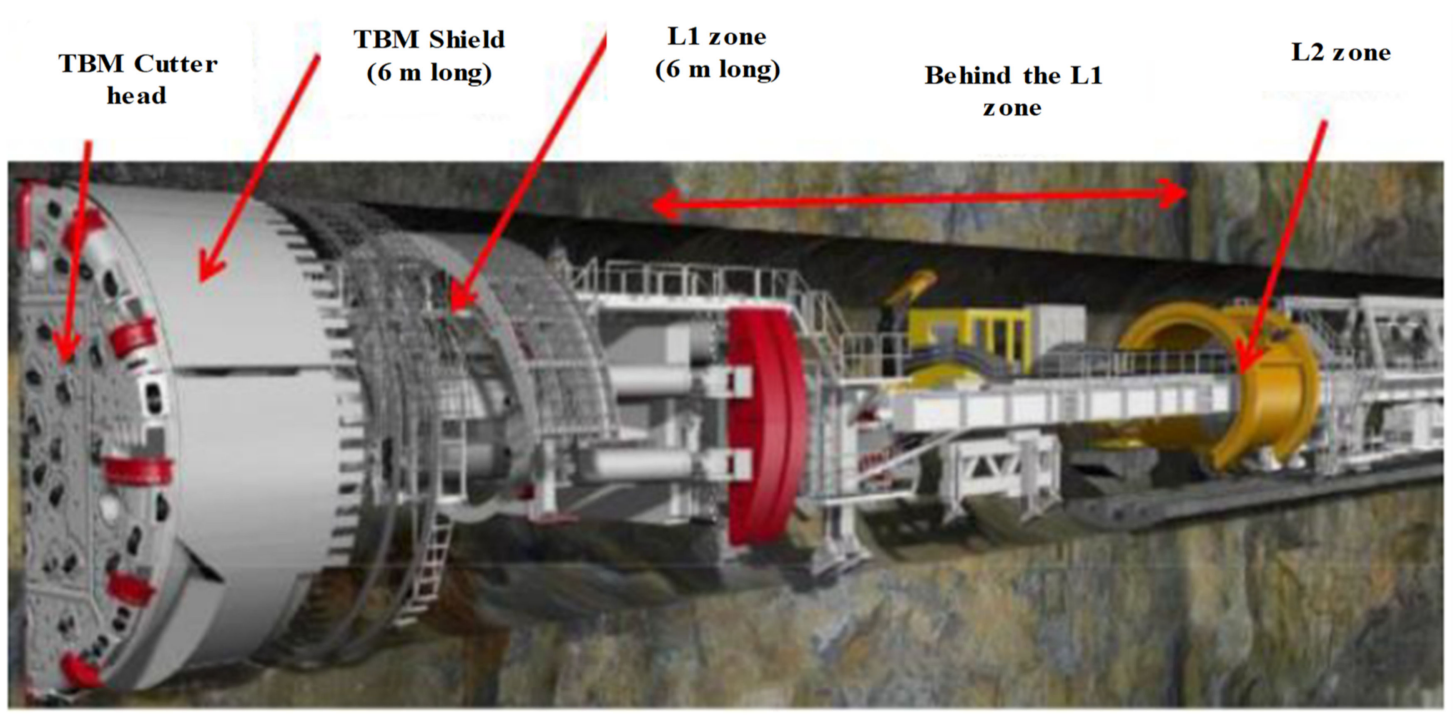

Figure 6. Open gripper tunnel boring machine. 
Initially, both machines were facilitated with two separate and independent systems for performing advance exploration, which are listed below [42]:

1. Tunnel Seismic Tomography System

2. Probe drilling

After the unexpected high horizontal stress prediction that substantially contributed to the severity of the rock bursts, two more investigation systems were added in the areas with frequent occurrences of rock bursts in order to measure the following: (1) the uniaxial compressive strength of the rock for rock burst prediction and (2) microseismic monitoring. Overcoring tests were conducted for measuring the in situ stress in this area to understand the in situ stress environment and avoid rock bursts [37].

When considering the stability after excavation, the main difference between the conventional and mechanical/TBM excavation approaches are the disturbances that they create in the rock mass at the periphery of the excavation site. In mechanical excavation, the disturbance in the rock mass is minimal, as compared to that in conventional excavation $[9,43]$. As the tunnel depth increases, the number of problems that are associated with high stresses also increases in TBM excavation [44]. At shallow depths, conventional excavation can cause undesirable effects, such as rock mass quality degradation, overexcavation, and blast vibration [45]. However, the negative effects (rock mass degradation) are actually helpful when tunneling through hard rocks at an overstressed depth. In this situation, the fractures that formed by blasting create a protected area through the migration of possible stress concentration away from the surrounding areas of the excavation, thus reducing the risk of rock bursts [46]. This is one of the reasons why rock bursts were rarely observed during the construction of the NJHEP. However, this conventional excavation approach requires the optimization of each activity in the tunnel construction cycle in order to accelerate the rate of advancement [47]. Table 4 lists the progress achieved through TBM-based tunneling and the conventional method of tunneling in Lot C2. In this project, the average progress realized using the TBM approach was 2-4 times higher than that afforded by the conventional tunneling method [48].

Table 4. Comparison of excavation progress in Lot C2 using different excavation methods.

\begin{tabular}{cccc}
\hline Tunnel Face & Tunneling Length (m) for All Faces & Working Days in All Faces & $\begin{array}{c}\text { Average Advance Rate } \\
\text { for All Faces (m) }\end{array}$ \\
\hline Single HRT using D\&B & 4433 & 1369 & 3.24 \\
Twin HRT using D\&B & 9823 & 5977 & 1.64 \\
Twin tunnels using TBM \\
$\begin{array}{c}\text { (avg. excavation activity is } \\
\text { 4.2 h/day/TBM) }\end{array}$ & 20,319 & 2849 & 7.13 \\
\hline
\end{tabular}

\section{Rock Burst}

\subsection{General}

In recent years, long and deep tunnels have been constructed in hydropower and transportation projects globally [49,50]. In these deep tunnels, rock burst is one of the most dangerous phenomena encountered during construction. During underground excavation, rock bursts occur during unloading, due to the excavation of the adjacent rock mass from the triaxial state in a high-stress environment. Tangential stress concentrations, which are a result of the rearrangement due to unloading that results from excavation, occur near the tunnel periphery, which can produce rock bursts. The abrupt unloading includes an extreme energy release from a hard rock mass, resulting in peripheral rock ejection, producing severe destruction to the equipment and the excavation process, and it may result in fatalities. The amount of stored energy and their release rate are responsible for the rock burst consequences in overstressed rocks. In rock mass, the stored elastic energy depends on in situ stresses and rock mass properties (particularly brittleness). The stress release rate in the form of energy depends on the excavation sequence in the high-stress 
zone and causes strain-type rock bursts. Other factors responsible for elastic energy storage in overstressed brittle rock masses, which, in turn, cause rock bursting, are geological structures, geological anomalies, and bedding orientation. In civil tunnels, rock bursts are predominantly of the strain type; however, fault-slip-type rock bursts also occur in the case of geological structural planes (shear zones or faults) [18]. Rock burst assessment is a key issue in deep excavation and it requires a thorough understanding of the phenomenon [51].

\subsection{Role of Geology, Excavation-Induced Stresses, and Method of Excavation in the Project}

In NJHEP, brittle failure of overstressed hard sandstone and slip along the structure plane both caused rock bursts [22]. The majority of rock bursts (81\%) occurred within the sandstone beds, while the remaining 19\% occurred within the massive siltstone beds, usually in close vicinity to sandstone beds at both tunnels that were excavated while using TBMs [30,36]. The two TBMs excavated the weak (siltstone) and strong (sandstone) interbedded rock, and the in-situ stress measurement campaign revealed that the orientation and amount of $\sigma_{1}$ (major principal stress) fluctuated considerably in the two layers. The $\sigma_{1}$ value is relatively high in the sandstone layer, and its direction is nearly perpendicular to the longitudinal axis of the tunnel. However, in the siltstone layer, the magnitude of $\sigma_{1}$ is significantly smaller than that of sandstone, and the direction is almost the same as that of the longitudinal axis of the tunnel [24]. The low value of $\sigma_{1}$ in the siltstone and its parallel orientation results in better tunnel stability with low deformation; therefore, squeezing rarely occurred during tunnel excavation. The tangential stresses from excavation were higher in the strong layers in the interbedded Murree formation, owing to the ability of the strong rock to store more energy. The maximum tangential stress, due to the redistribution, was high in the sandstone layer and rock bursts frequently occurred in this layer.

After the heavy rock burst that occurred on 31 May 2015, a shear plane-like structure was observed in the wall of the tunnel that was excavated by TBM 696 [25]. The investigation indicated that there is an association between the occurrence of rock bursts and shear zones and high in situ stress. The shear zone structure performed the role of stress accumulation in the high-stress environment, which resulted in a situation that was favorable for the occurrence of abrupt shear failure. This abrupt failure released the accumulated energy in the form of a rock burst. The quantity of energy that is stored owing to the presence of a shear zone is a function of the rock type and in situ stress conditions. The hard rock has the capacity to store more energy; therefore, if the presence of a shear zone results in a stress concentrating barrier in the vicinity, it can produce intense rock bursts [38].

The low strength-stress ratio and/or type of geological structure are the major factors that are responsible for stability during tunneling [52]. Fortunately, the tunnel excavation process in identical situations with jointed rock masses is relatively unfavorable for rock bursting $[53,54]$. Therefore, rock bursting was a major challenge for TBM-based tunneling only when comparing the excavation methods (conventional versus TBM) in NJHEP [18,32]. In the conventional method of excavation, the modulus of elasticity decreases (and the level of decrease depends on the blasting quality), owing to fracturing and rock deformation. Consequently, the migration of excavation induces stresses that occur away from the tunnel periphery and result in a decrease in rock burst risk $[9,55,56]$.

\subsection{Actual Rock Burst Situation}

Over 1700 rock bursts were acknowledged during the twin TBM-based headrace tunnel excavations of the project, of which 55 were of Category 3 magnitude or greater (Figure 7). Rock bursts and overbreaks frequently occurred during the headrace tunnel excavation, and one intense rock burst not only damaged the TBM, but also resulted in a loss of life of workers. 


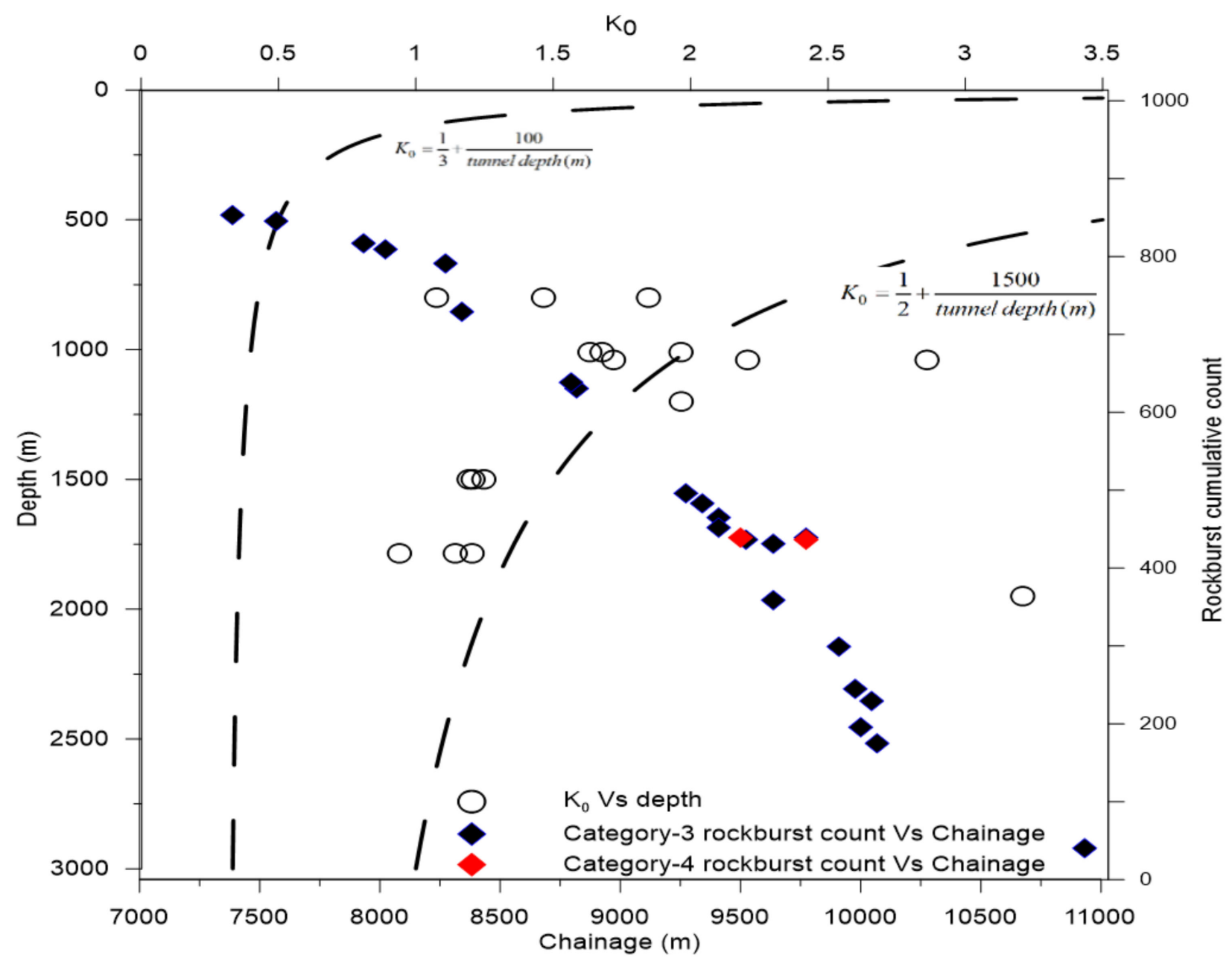

Figure 7. High in-situ stresses due to tectonics and the rock burst count in the headrace tunnels due to these stresses in the area (modified after [38]).

On 31 May, a severe burst occurred from chainage $09+706$ and $09+793$ in the right headrace tunnel (TBM 696). Figure 8 shows the over-excavation profile. Three personnel expired, and a few were wounded after the rock burst. Further, a considerable volume of the walls and crown collapsed, which resulted in damage to the TBM. The shockwave that was generated by the rock burst caused damages to the adjacent parallel headrace tunnel, which was being mined by TBM 697 [18]. According to Mierzejewski, the rock bursts encountered in the project were all self-initiated strain bursts, in contrast to events that may be triggered by distant seismic events; however, certain researchers indicate that fault-sliptype rock bursts also occur during the TBM-based excavations [22,38]. The occurrence of rock bursts at the tunnel face was rare; however, during TBM-based excavation, the reorientation of stresses can cause rock bursts and almost two-third of the events occurred in this situation. One-third of the rock bursts occurred during support installation in the L1 section. One-half of the total rock burst events occurred in this risky section of the TBM (L1 zone), where the activity was high without any protection, particularly during the support installation period [30]. 


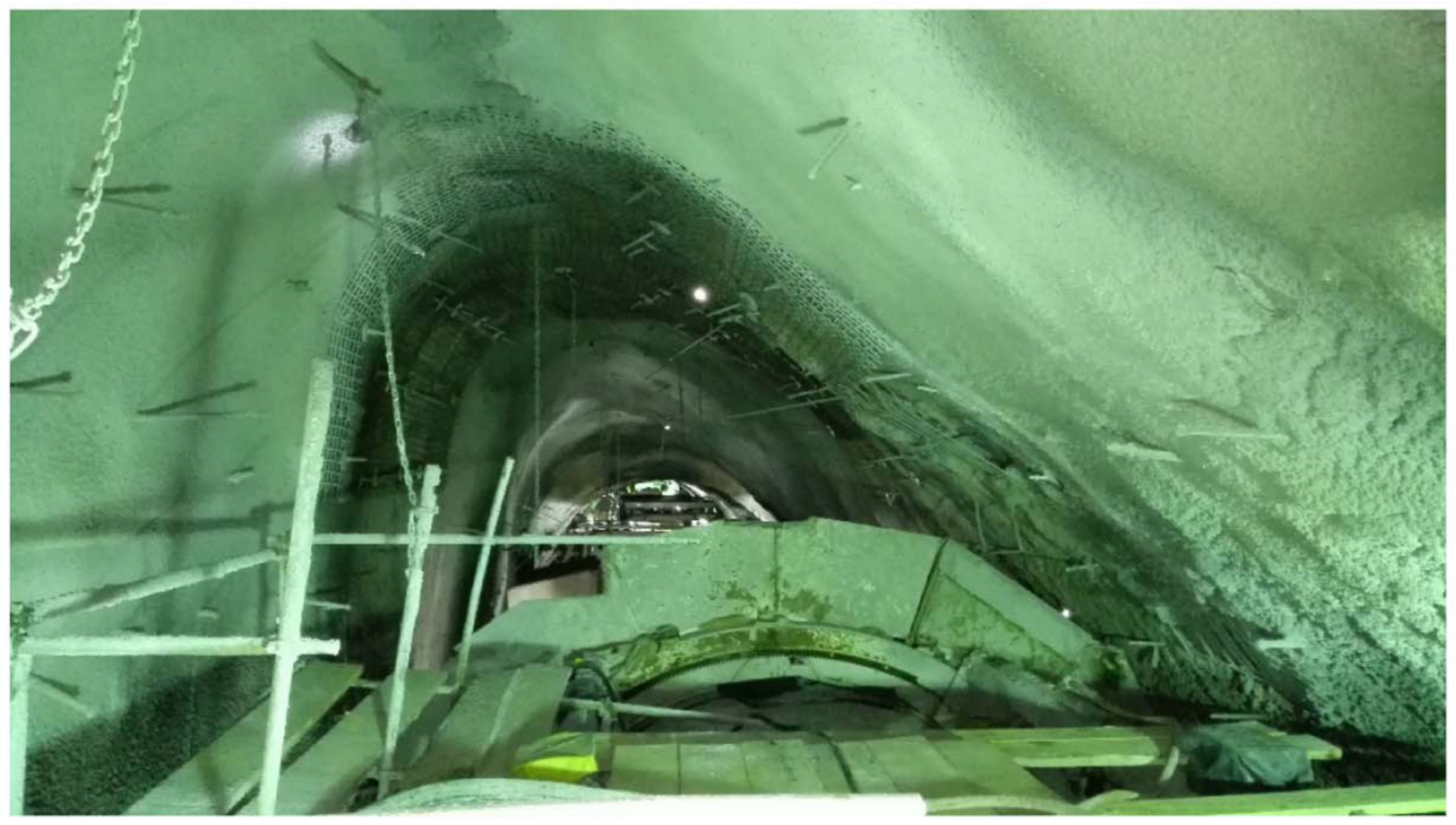

Figure 8. Over-excavation profile of the headrace tunnel after the rock burst on 31 May.

The rock burst event of May 31 was due to the sudden slip of the shear zone during the excavation and sudden release of energy (which was stored because of this energy barrier), according to Naji et al. This rock burst was similar to those that occurred in the drainage tunnel of the Jingping II hydropower project in China [57] and the diversion tunnel of the Tianshengqiao hydropower project [58]. The rock burst in one headrace tunnel not only created damages and losses in the TBM 696, but it also affected the adjacent tunnel owing to its dynamic behavior [21].

\subsection{Rock Burst Prediction Criteria for Neelum-Jhelum Hydroelectric Project}

The traditional rock burst prediction approaches are based on the rock strength in practice, while the actual occurrence of rock bursts depends more on the structure and strength of the rock mass $\left(\sigma_{\mathrm{cm}}\right)$. Naji and his co-researchers used different parameters, i.e., stress reduction factor (SRF), $\sigma_{\theta} / \sigma_{\mathrm{c}}, \sigma_{\mathrm{t}} / \sigma_{1}$, and $\sigma_{\mathrm{c}} / \sigma_{1}$ for rock burst estimation using the conventional rock burst criteria [59-61], for five dangerous chainages along the headrace tunnel of a project with predicted heavy rock burst [18]. For design engineers, the traditional rock burst criteria are appropriate for understanding the causes; however, it is too simple and conservative to forecast rock burst occurrence in complex geological environments. The prediction criteria, which are based on the strength-to-stress ratio, measure the strength of the rock, which is attained from laboratory tests; however, they ignore the consequence of the in situ stress effect on $\sigma_{\mathrm{cm}}$ [31]. When considering the influencing factors and limitations of traditional rock burst criteria, a comprehensive study was conducted based on the data that were related to the characteristics of the rock bursts that occurred during NJHEP construction, and a novel rock burst criterion was proposed [23]. This criterion utilizes the rock mass strength-stress ratio. This ratio is between $\sigma_{\mathrm{cm}}$, based on the Hoek-Brown strength criterion, and $\sigma_{\mathrm{H}}$, which is perpendicular to the longitudinal axis of the tunnel. The criterion also considers other factors that influence rock burst, i.e., rock mass characteristics, construction disturbances in the vicinity, and the geologic structure.

A close relation exists between the rock burst and the stored energy release rate during excavation; moreover, the unloading-confining-pressure-based energy criteria is another approach for the evaluation of rock bursts in the NJHEP, which is defined in Equation (2) [62]. Before excavation, the elastic energy storage in the rock mass is due 
to in situ stresses, which is followed by excavation-induced redistributed stresses in the excavation surroundings.

$$
\frac{U^{e}}{U^{e-\max }}=\mid \begin{array}{ll}
\geq 0.7 & \text { (severe rockrurst) } \\
0.5 & \text { (strong rockburst) } \\
0.4 & \text { (medium rockburst) } \\
0.3 & \text { (weak rockrurst) }
\end{array}
$$

Before failure is attained, $U^{e-\max }$ is the maximum storage elastic energy of the rock. This energy is before the occurrence of failure and it is achieved from the unloading confining pressure tests. The storage elastic energy of the rock mass is represented through $U^{e}$, owing to in-situ stresses and excavation. From the NJHEP sandstone stress-strain curve, the three parts of the store elastic energy are as shown below [31]:

$$
U^{e}=U_{h}^{e}+U_{l}^{e}+U_{u}^{e}
$$

where $U_{h}^{e}$ is the storage elastic energy during the application of the hydrostatic pressure, $U_{l}^{e}$ is the storage elastic energy during the application of the initial axial stress, and $U_{u}^{e}$ is the storage elastic energy during unloading confining pressure. $U_{h}^{e}$ can be calculated, as follows:

$$
U_{h}^{e}=\frac{3(1-2 \times v) \times\left(\sigma_{3}^{0}\right)^{2}}{2 \times E},
$$

where $v$ is Poisson's ratio, $E$ is the elastic modulus of the rock specimen, and $\sigma_{3}^{0}$ is the initial confining pressure. The storage elastic energy during the application of the initial axial stress can be calculated, as follows, where $\sigma_{1}^{u}$ is the maximum axial stress at the maximum confining pressure.

$$
U_{l}^{e}=\frac{1}{2 \times E}\left[\left(\sigma_{1}^{u}\right)^{2}-\left(\sigma_{3}^{0}\right)^{2}-4 \times v \times\left(\left(\sigma_{1}^{u} \times \sigma_{3}^{0}+\left(\sigma_{3}^{0}\right)^{2}\right)\right]\right.
$$

During the unloading process, the storage elastic energy $U_{u}^{e}$ is:

$$
\begin{gathered}
U_{u}^{e}=\frac{1}{2 \times E_{u}} \times\left[\left(\sigma_{1}^{p}\right)^{2}+2 \times\left(\sigma_{3}^{r}\right)^{2}-2 \times v_{u} \times\left(2 \times \sigma_{1}^{p} \times \sigma_{3}^{r}+\left(\sigma_{3}^{r}\right)^{2}\right)\right] \\
-\frac{1}{2 \times E} \times\left[\left(\sigma_{1}^{u}\right)^{2}+2 \times\left(\sigma_{3}^{0}\right)^{2}-2 \times v_{u} \times\left(2 \times\left(\sigma_{1}^{u}\right)^{2} \times \sigma_{3}^{0}+\left(\sigma_{3}^{0}\right)^{2}\right)\right]
\end{gathered}
$$

where $E_{\mathrm{u}}$ and $v_{\mathrm{u}}$ are the unloading elastic modulus and Poisson's ratio of the specimens, respectively. Moreover, $\sigma_{1}^{p}$ and $\sigma_{3}^{r}$ are the axial and radial stresses at the peak value of the stress-strain curve during the unloading confining pressure test. The experimental results reveal that $\mathrm{E}$ is lower than $E_{\mathrm{u}}$ and $v_{\mathrm{u}}$ is smaller than $v$ [63]. For the NJHEP sandstone, $v_{\mathrm{u}}$ and $E_{\mathrm{u}}$ are 0.96 times the Poisson's ratio of sandstone and 1.07 times the elastic modulus of sandstone. Based on 15 tests and Equations (3)-(6), the calculated maximum stored elastic energy is as listed in Table 5. A severe rock burst phenomenon occurred because the elastic energy is higher than $300.5 \mathrm{~kJ} / \mathrm{m}^{3}$ [62]. Based on the study, a strong correlation exists with a higher correlation coefficient (0.95) between the maximum storage elastic energy and the initial confining pressure, which is represented, as follows:

$$
U^{e-\max }=275.7 \times \exp \left(0.0285 \times \sigma_{3}^{0}\right) .
$$


Table 5. Unloading confining stress results for sandstone in the Neelum-Jhelum Hydroelectric Project.

\begin{tabular}{|c|c|c|c|c|c|}
\hline Test No. & $\sigma_{3}^{0}(\mathrm{MPa})$ & $v$ & E (GPa) & Peak Deviatoric Stress (MPa) & $U^{e-\max }$ \\
\hline 1 & \multirow{3}{*}{35} & 0.26 & 40.2 & 250 & 820 \\
\hline 2 & & 0.22 & 35.9 & 245 & 866.5 \\
\hline 3 & & 0.24 & 38.3 & 246 & 833.4 \\
\hline 4 & \multirow{3}{*}{45} & 0.23 & 34.2 & 269 & 1114.3 \\
\hline 5 & & 0.24 & 40.3 & 282 & 1053.1 \\
\hline 6 & & 0.27 & 51.7 & 283 & 898 \\
\hline 7 & \multirow{3}{*}{55} & 0.22 & 32.1 & 267 & 1363.9 \\
\hline 8 & & 0.24 & 32.8 & 286 & 1445.8 \\
\hline 9 & & 0.23 & 32.7 & 285 & 1434 \\
\hline 10 & \multirow{3}{*}{65} & 0.28 & 52.4 & 336 & 1667.5 \\
\hline 11 & & 0.21 & 29.1 & 329 & 1909.8 \\
\hline 12 & & 0.24 & 30.8 & 301 & 1788.8 \\
\hline 13 & \multirow{3}{*}{75} & 0.23 & 28.0 & 338 & 2233.2 \\
\hline 14 & & 0.25 & 35.0 & 357 & 2097.9 \\
\hline 15 & & 0.25 & 38.3 & 353 & 1801.8 \\
\hline
\end{tabular}

\section{Extension of Empirical Classification Systems for Tunnel Support Design}

\subsection{General}

The previous experience from tunneling is the basis for the development of empirical classification systems and it is now used worldwide in the design and construction of underground excavation systems, particularly for their support recommendation. In these systems, the descriptive methods that are followed by numerical characterization is used for the design parameters $[64,65]$. In the case of complex rock mass, this characterization process is not appropriate for rock mass classification in existing systems; therefore, modification is required in existing systems for appropriate utilization [66]. The rock mass assessment in a precise way is important for a suitable excavation approach as well as for construction schedule development and proper support selection. This assessment of rock mass and its further use in tunnel design and construction through empirical classification are undeniably the best evaluation methods [67]. From the middle of the 20th century, approximately a dozen classification systems for rock masses have been offered with consideration of different purposes in rock engineering. Of these, only a few have gained international recognition, including rock mass rating (RMR) $[6,68,69]$ and tunneling quality index $(Q)$, in the tunnel support design field. The different characterization parameters combine in a unique way in their different versions (as shown in Equations (8)-(12)) [8].

$$
\begin{gathered}
R M R_{89}=R_{1}+R_{2}+R_{3}+R_{4}+R_{5}+R_{6} \\
R M R_{13}=R_{1}+R_{2-3}+R_{4}+R_{5}+R_{6} \\
R M R_{14}=\left(R M R_{b}+F_{0}\right) \times F_{s} \times F_{e} \\
Q=\frac{R Q D}{J_{n}} \times \frac{J_{r}}{J_{a}} \times \frac{J_{w}}{S R F} \\
Q_{c}=\frac{R Q D}{J_{n}} \times \frac{J_{r}}{J_{a}} \times \frac{J_{w}}{S R F} \times \frac{\sigma_{c}}{100}
\end{gathered}
$$

$R M R_{89}, R M R_{13}$, and $R M R_{14}$ are the RMR versions of 1989,2013 , and 2014, respectively, while $Q$ and $Q_{c}$ are the original and modified versions of $Q$ classification systems, respectively. Because these systems are based on a conventional shallow tunneling database, 
excavated in jointed rock mass, their application as a design tool is acceptable for similar tunneling. In the case of deep tunneling under high stresses, the $Q$ system has an SRF for massive rock conditions, but both of the systems have limitations in a highly stressed jointed rock mass environment [32].

Based on the data of NJHEP and other projects in the area, where conventional excavation progressed through jointed rock mass under high overburden, the aforementioned systems were empirically extended through a back-calculation approach [70]. In this approach, the thickness of shotcrete and spacing of the rock bolt were applied with the tunnel span in the support chart for the RMR and Q systems. In tunnel composite support, the contribution of the rock bolt and shotcrete to the support are different, owing to numerous factors; therefore, no criterion is available for choosing rock-bolt-spacing-based rock mass quality $\left(\mathrm{Q}_{2}{ }^{*}\right.$ and $\left.\mathrm{RMR}_{2}{ }^{*}\right)$ and shotcrete thickness, along with tunnel-span-based rock mass quality $\left(\mathrm{Q}_{1}{ }^{*}\right.$ and $\left.\mathrm{RMR}_{1}{ }^{*}\right)$ weightage for the back calculation [71]. Therefore, five cases were chosen, and Table 6 lists the details [72]. The table lists the different weightage values of the back-calculated rock mass from the rock bolt spacing and shotcrete thickness.

Table 6. Different weights selected for the rock-mass-quality back calculation.

\begin{tabular}{ccc}
\hline Case No. & Weightage of $\mathbf{Q}_{\mathbf{2}}{ }^{*}$ and $\mathbf{R M R}_{\mathbf{2}}{ }^{*}$ & Weightage of $\mathbf{Q}_{\mathbf{1}}{ }^{*}$ and $\mathbf{R M R}_{\mathbf{1}}{ }^{*}$ \\
\hline 1 & Actual & 100 \\
2 & 50 & 75 \\
3 & 50 & 50 \\
4 & 75 & 50 \\
5 & 100 & 50 \\
\hline
\end{tabular}

\subsection{Extension of the Tunneling Quality Index System}

Figure 9 shows the SRF calculation technique. The five different weights listed in Table 6 are used, and Equation (10) is rearranged and incorporated in Figure 9. The bolt length was correlated with the excavation support ratio value, which revealed that one is an appropriate value for hydropower projects [73,74].

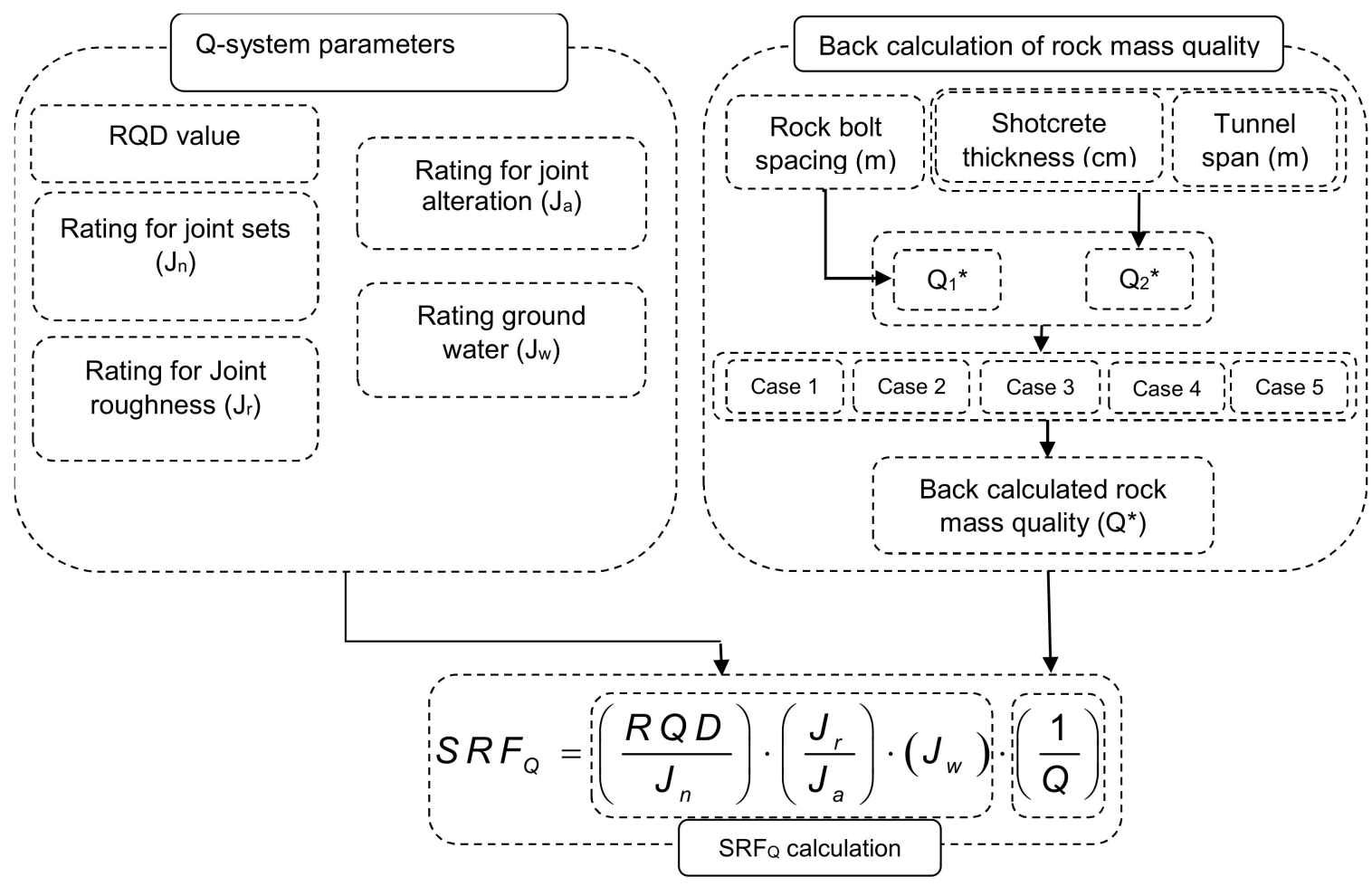

Figure 9. Procedure for calculating the stress reduction factor, while considering the five cases listed in Table 6 (modified after [32,72]). 
The SRF obtained from Figure 9 is used for the equation derivation for the extension of the $Q$ system to a highly stressed jointed rock mass environment. Equations (13) and (14) are derived based on weightage cases 1 and 3 , respectively [32,75]. These equations show that SRF is a function of the strength-stress $\left(\sigma_{c} / \sigma_{1}\right)$ ratio and relative block size $\left(R Q D / J_{n}\right)$.

$$
\begin{gathered}
S R F_{Q}=2.054 \exp \left(0.205 \frac{R Q D}{J_{n}}\right)+14.865 \exp \left(-0.41 \frac{\sigma_{c}}{\sigma_{1}}\right) \\
S R F_{Q}=2.0 \times \exp \left(0.21 \times \frac{R Q D}{J_{n}}\right)+12.0 \times \exp \left(-\alpha \times \frac{\sigma_{c}}{\sigma_{1}}\right)
\end{gathered}
$$

\subsection{Extension of Rock Mass Rating System}

The methods for introducing a stress adjustment factor $\left(F_{\text {stress }}\right)$ are shown in Figures 10 and 11 for the two versions of the RMR system. For this purpose, three different hypotheses were tested for determining $F_{\text {stress }}$ for $R M R_{89}$ and $R M R_{14}$ for determining the tunnel support design in a specific rock mass environment. The five weightage cases that are listed in Table 6 are used. Using three hypotheses and the five weightage cases, the $F_{\text {stress }}$ values for tunnel support design are proposed for Equations (8) and (10), which are as expressed in Equations (15) and (16), and Table 7 lists their values [32].

$$
\begin{aligned}
& R M R_{89}^{*}=R M R_{89}+F_{\text {stress }-89} \\
& R M R_{14}^{*}=R M R_{14}+F_{\text {stress }-14}
\end{aligned}
$$

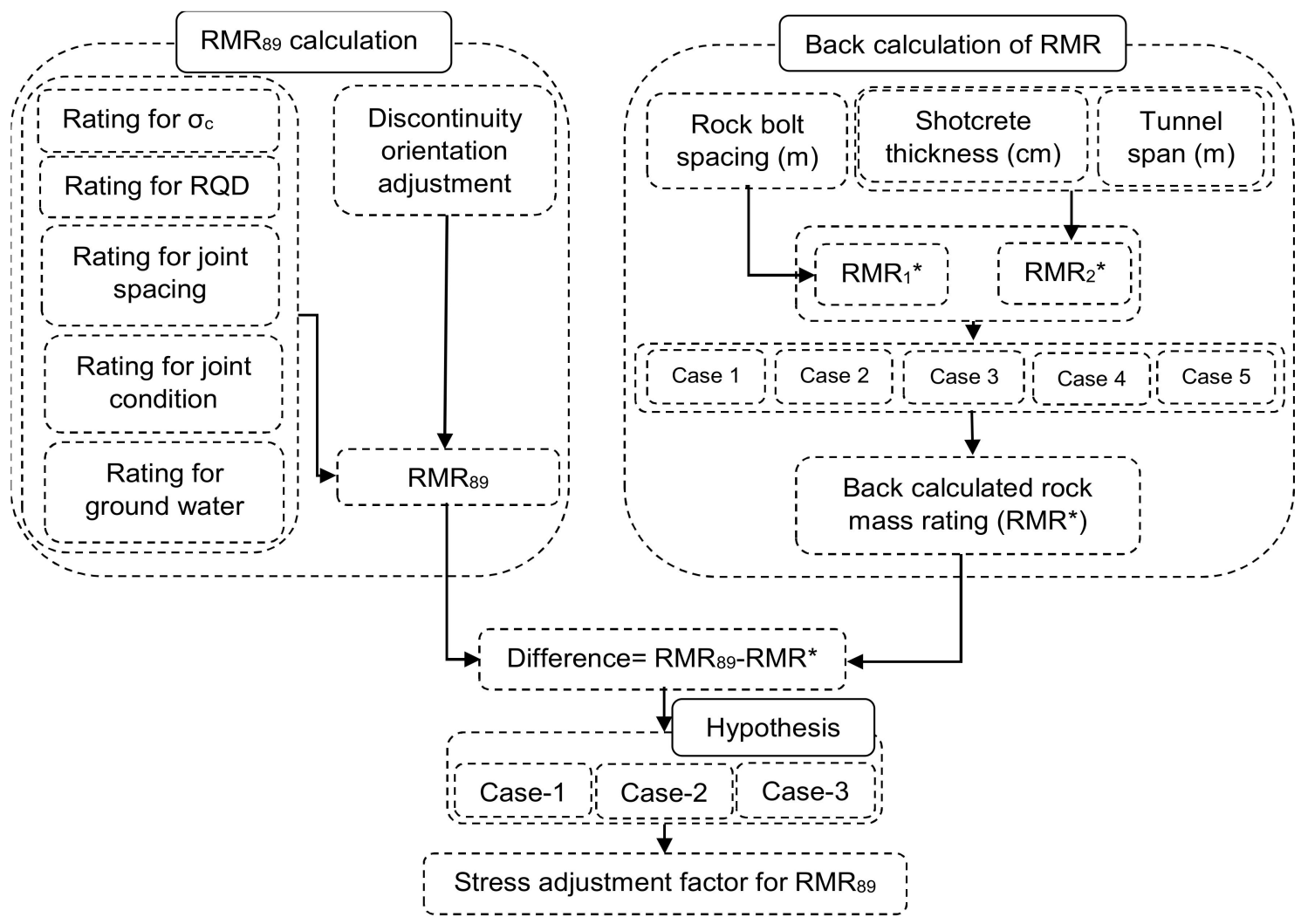

Figure 10. Procedure for determining stress adjustment factor $\left(F_{\text {stress }}\right)$ in rock mass rating ${ }_{89}\left(R_{M} R_{89}\right)$, while considering the five cases listed in Table 6 (modified after [32,72]). 


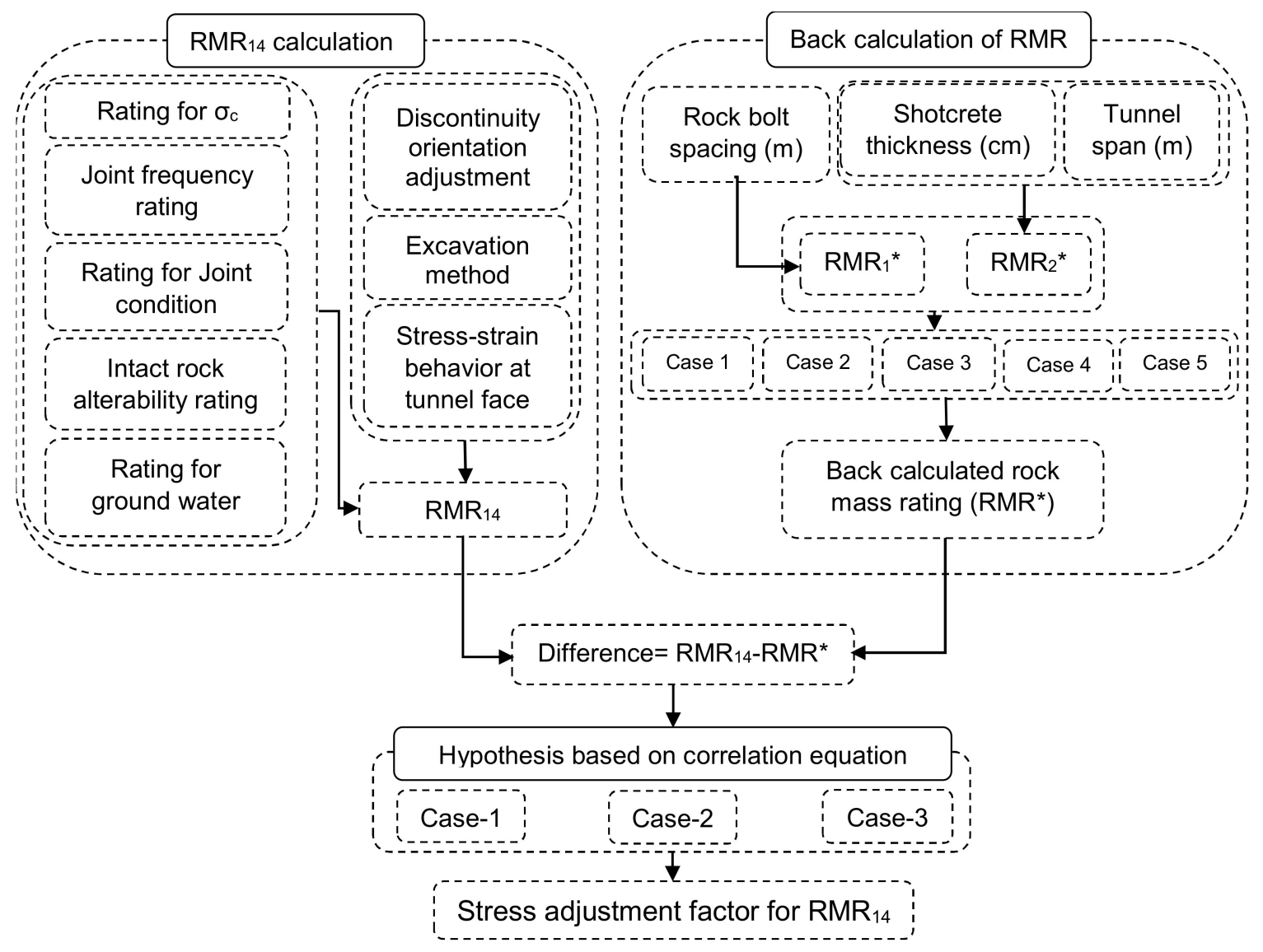

Figure 11. Procedure for determining $\mathrm{F}_{\text {stress }}$ in $\mathrm{RMR}_{14}$, while considering the five cases listed in Table 6 (modified after [32,72]).

Table 7. $\mathrm{F}_{\text {stress }}$ based on strength-stress ratio for the two versions of rock mass rating.

\begin{tabular}{cccc}
\hline & \multicolumn{3}{c}{ Values of $\boldsymbol{\sigma}_{\mathrm{c}} / \boldsymbol{\sigma}_{\mathbf{1}}$} \\
\cline { 2 - 4 } RMR Version & $4-5$ & $3-4$ & $2-3$ \\
\cline { 2 - 4 } & & $\mathrm{F}_{\text {stress }}$ & -15 \\
& -5 & -10 & -32.012 \\
\hline RMR89 & -22.326 & -27.169 & \\
\hline
\end{tabular}

\section{First Filling of Headrace Tunnel}

After project completion, the successful re-saturation of the headrace tunnel was crucial for design verification. Tunnel stability and water leakage were critical, because of the complex geological environment in this super-long tunnel. The structural reliability of tunnel lining is significantly reliant on several parameters, including rock types, strength of the rock mass, structural features, tectonic setup, and groundwater levels [76]. According to Panthi, in the case of a shotcrete-lined tunnel, the maximum limit for leakage per linear meter of tunnel is $0.31 \mathrm{~L} / \mathrm{min}$; however, for an economic solution, a limit ranging from 1 to $1.5 \mathrm{~L} / \mathrm{min}$. is acceptable [77].

The tailrace tunnel filling of NJHEP was started first (13 January 2018), followed by the filling of the headrace tunnel (6 March 2018). A slow filling process was implemented with six controlled stages to avoid cracks in the liner and maintain tunnel safety. The tunnel filling rate was $1.5 \mathrm{~m}$ /day with intermittent pauses of $24 \mathrm{~h}$ between each stage [78]. Figure 12 shows the headrace tunnel water-filling stages and corresponding pauses, along with water loss due to leakage. 


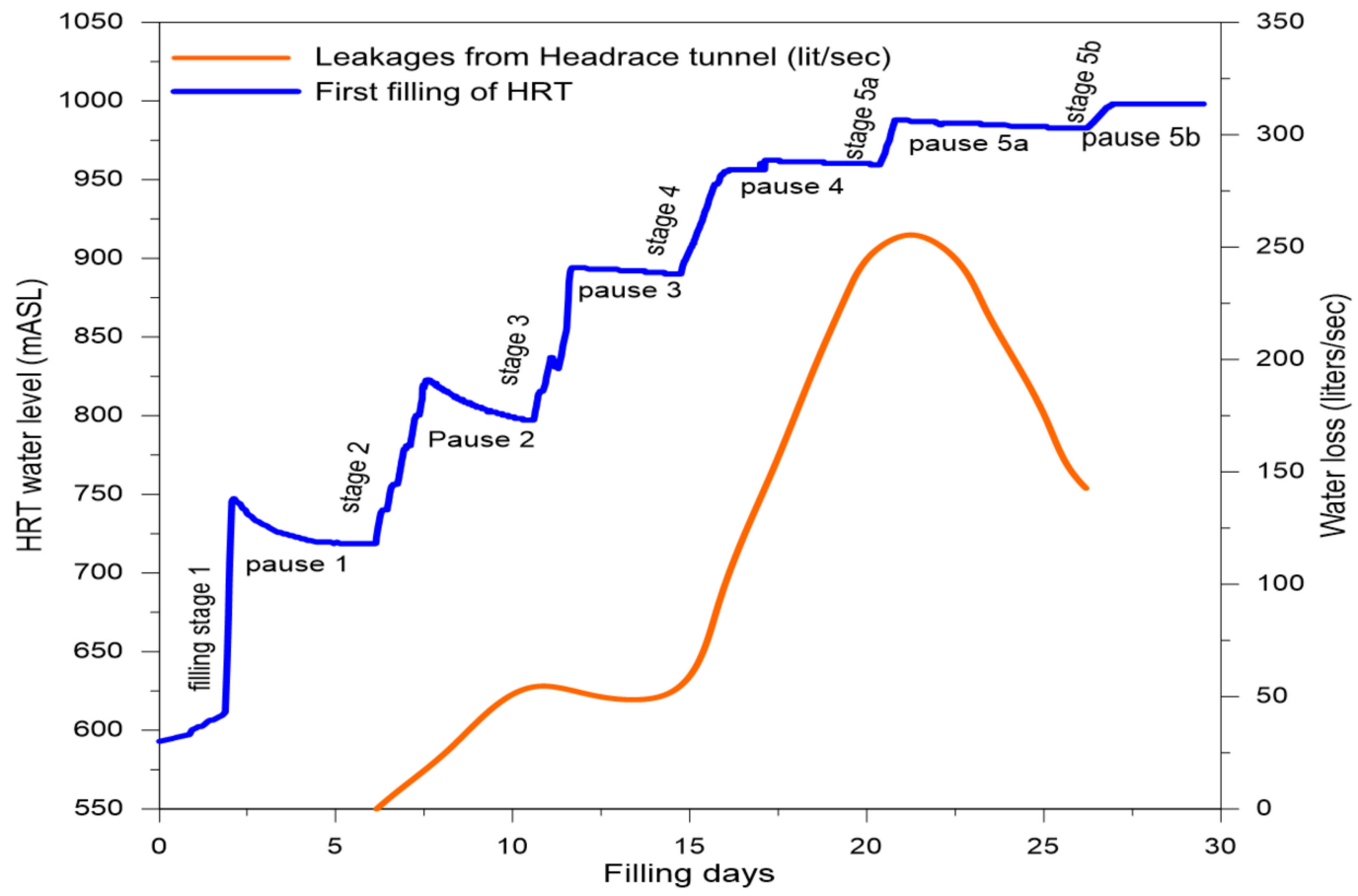

Figure 12. Filling stages and water loss during headrace tunnel filling.

The major aims of the headrace tunnel filling were as follows: (1) to apply less drastic forces on the concrete liner; (2) fill with increments in pressure; (3) allow time to monitor for leakages and hydro-jacking; (4) provide time to monitor, quantify, and stabilize the water loss; and, (5) minimize hydraulic gradients during the initial saturation of the rock mass [28].

This stepwise filling operation was mandatory in avoiding unnecessary pressure buildup on the tunnel lining. The inherent geology was characterized by open joints and leakages at places, although these were dried later after excavation. During filling, back loading on the liner, as well as strength reduction of the rock mass, were expected.

Figure 13 shows the seepage response in the powerhouse and auxiliary structures during the first filling of the headrace tunnel. The leakage responses were high in adits A4 and A4a when compared to other leakage observations. The adit A4 runs parallel to the headrace tunnel. The maximum leakage was due to the small pillar width (approximately $50 \mathrm{~m}$ ), which was an expected response. There was a sudden increase in leakages in adit A4a, which was caused by post-water up-grouting in adit A4, as shown in Figure 13. This is reflected in the results, as the leakage rate in adit A4 decreased, owing to grouting, and the leakage increased in adit A4a in parallel.

During the actual tunnel filling operation, the consolidated grouting work and drainage system worked effectively, with no deformation in the rock mass around the caverns. No significant changes in the extensometers, load cells, and convergence points/targets were noted during the filling operation. However, observations at certain piezometers revealed that water flow occurred in the sandstone beds and the overall leakage was within the design/permissible limit. During the tunnel filling and re-saturation operation, overall, the geomechanical instruments did not show any significant change. 


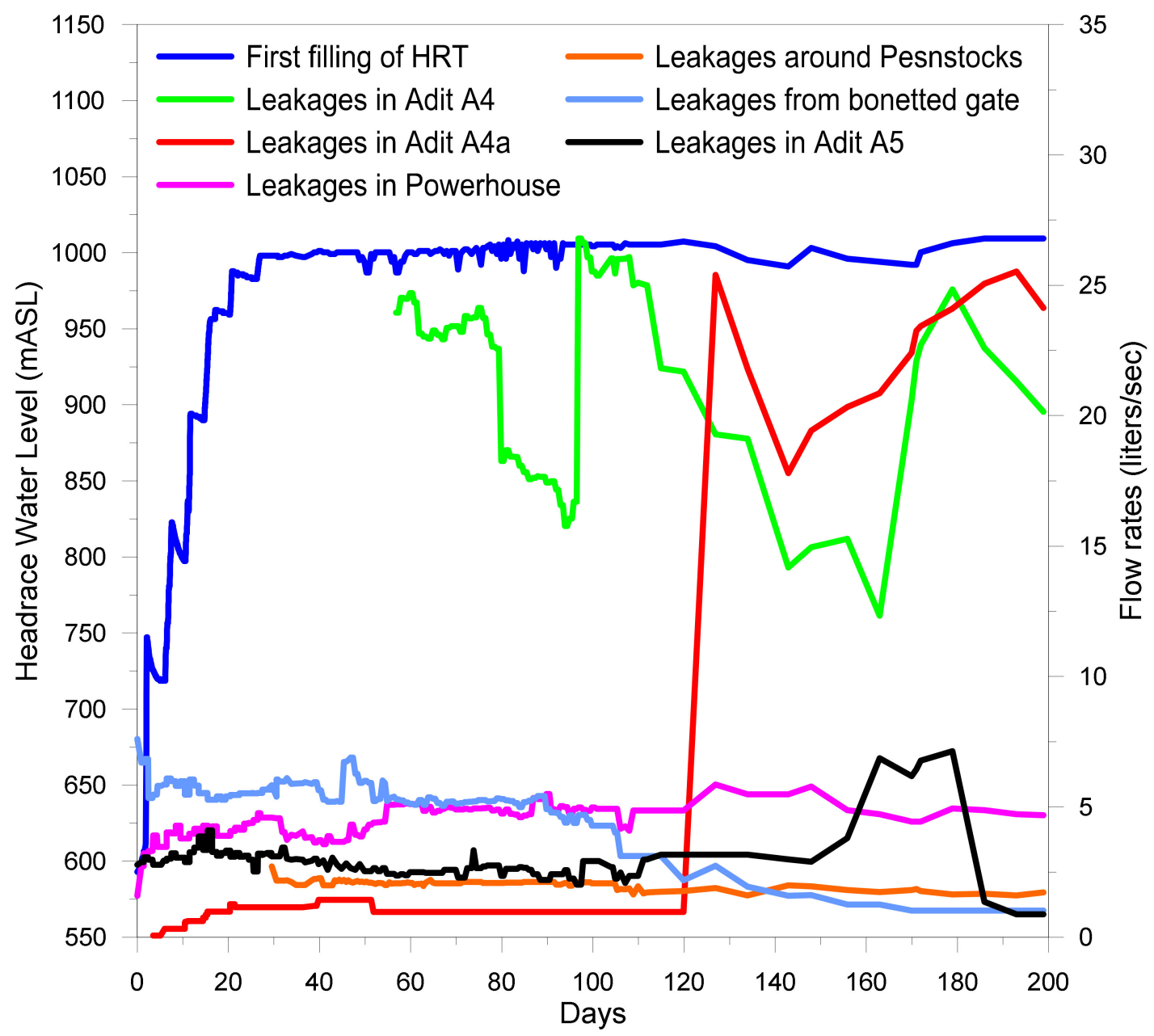

Figure 13. Filling of the headrace tunnel and subsequent infiltration into the adits, drainage gallery, and powerhouse.

\section{Discussion}

Hydroelectric projects have been developed in the Himalayan mountain range in the northern part of the country with plans for future developments in order to satisfy the increasing demand for energy in Pakistan. However, during the underground excavation in the Himalayan region, several technical challenges pertaining to the design and construction of these hydroelectric projects are encountered, including high overburden, regional tectonics, insufficient exploration during feasibility studies, complex geology, virgin and excavation-induced stresses, and the presence of groundwater. These adverse conditions produce risks not only during construction in terms of huge rock mass failure, rock bursts, squeezing, and flooding, but also during the operational phase of the project, as experienced during the construction and operation of the NJHEP. The major focus of this research is deep underground tunneling, which is not so common. There are few examples of such deep civil engineering tunnels in recent literature. The Jinping II hydropower project is one of those referred in this manuscript that have faced the same challenges, like NJHEP. The successful completion of the complex NJHEP in the challenging and unique in-situ environment of the Himalayas is a great experience for the study of a significantly deep civil tunneling process. Rock burst was the main problem during tunneling in this part of Himalayas, which has great implications on human life and property. In the future, many tunneling projects are planned in this area, due to its great hydropower potential. This study provides a valuable reference, not only for research in relevant fields, but also for the planning and construction of deep underground excavations worldwide, and specifically, in the Himalayas. 
The project-related features performed a critical role in the successful completion of the significantly long excavation work of the NJHEP under the difficult geological conditions. New methods and models have been applied and developed based on the experience of the project, which have significantly contributed to the research on rock mechanics and are reviewed in this paper.

The project layout indicates that the tunnels experienced a number of challenges in their route. These challenges include the complex geology of the Himalayas with unique sedimentary settings at significant depths (up to $2000 \mathrm{~m}$ overburden), abnormal stress conditions $\left(\mathrm{K}_{0}>3.0\right)$, the presence of fault zones, and river crossing under low overburden. The intact rock and rock mass properties are different for the same type of rock along the tunnel route and under different overburdens, which was determined based on the results that are summarized from the test campaign conducted during the project. A combination of the single and twin headrace tunnels was completed with both conventional and mechanized excavation methods. The actual problems encountered during construction included the prediction of actual rock mass behavior ahead of the excavation, slow progress from conventional excavation, rock burst occurrences during TBM-based excavation, water inrush problem in fault zones, and water leakage problems during the construction stage of the project.

During the project construction period, the construction strategy was revised at different times for its timely completion. The primary modification was the decision to use TBM instead of the conventional approach in a specific section of the headrace tunnel. Although modifications were adopted for accelerating the tunnel construction, the challenges faced in the Jhelum river crossing, presence of fault zones, occurrence of natural disasters, and changes in policies were the major factors responsible for project delay [48]. Although the TBM-based tunneling progressed faster than the conventional excavation process, this progress was lower than expectations, owing to high stresses and rock burst events. The conventional excavation progress was comparatively lower in the twin headrace tunnel, although its cross section is smaller than that of a single headrace tunnel, as can be observed from Table 4 . The primary reasons are the challenges that are associated with the MF, Jhelum river crossing, and TBM assembly chamber.

From the geotechnical data of this project, the rock face mapping results, along with the installed supports, are used for the rock-mass-quality back calculation and the extension of the empirical rock mass classification system for the relevant ground. Advance ground investigation systems were used in TBMs, and an overcoring method was adopted for in situ stress determination in the areas that were highly susceptible to rock bursting. The high stress concentration in the strong rock units caused core discing in the sandstone layer in several tests, and the successful results were lower than the actual number of tests that were performed, owing to the interbedded layers of the Murree formation. The different chapters of the paper reveal that in a high tectonic stress zone, the elastic energy stored in the rock mass depends on the rock mass properties, excavation sequence, orientation of the in situ stress, and magnitude of strength-stress ratio. During tunnel excavation, the uneven concentration of stresses in the different layers frequently caused rock bursts in the stronger layer in the high-stress in situ environment. Therefore, drilling ahead of the cutter head detects the presence of sandstone; consequently, stress relief holes were drilled prior to the excavation while using TBMs. In this area, the available criteria for rock burst forecast were convenient for consideration during the design stage; however, it was difficult to accurately predict them in the complex geological environment of the project. Therefore, a new criterion was proposed based on the project data. In the interbedded layers of strong and weak rock units, the low concentration of excavation-induced stresses in the weak layers and their favorable orientation rarely caused the squeezing problem in the excavation process in the headrace tunnel. Along with pre-excavation grouting, a temporary tunnel plug was used in areas with severe groundwater challenges in the fault zone below the Jhelum river crossing; moreover, these areas were steel lined to counteract the hydro-fracturing in this low-confining stress area. Pre- and post-excavation grouting 
campaigns were implemented at various stages of the project to reduce water leakage, for ease of excavation, to fill open discontinuities and voids that may serve as leakage paths within the rock mass, and to reduce the potential for seepage and migration of high-pressure water.

\section{Conclusions}

1. The successful completion of the complex NJHEP in the challenging and unique insitu environment of the Himalayas is a great experience for the study of a significantly deep civil tunneling process. This experience will be helpful and it will be a baseline for future underground excavations and research in relevant environments.

2. The study concluded that the latest techniques, such as overcoring for in situ stress determination and microseismic prediction systems for advance ground investigation, should be adopted in a timely manner for identifying the exact location and time of rock burst occurrences.

3. Strict safety measures and better planning must be adopted against rock burst occurrence to ensure safety for human life and capital.

4. The role of project-related features is as important as that of rock mass quality, in situ stresses, and groundwater for proper planning and the successful completion of projects in the significantly long underground excavation projects. Although modification in the project related features can improve the tunnel construction progress, adverse ground composition not only reduces the efforts during construction, but also creates complications during tunnel operation.

5. There are few examples of deep civil engineering tunnels in the world. Therefore, this study provides a valuable reference not only for research in relevant fields, but also for the planning and construction of deep underground excavations worldwide, and, specifically, in the Himalayas.

Author Contributions: H.-K.Y. supervised the research. H.R. developed the proposed research concept. A.M.N. and K.N. contributed to reviewing the final paper and made important suggestions and recommendations for paper revision. S.A. and K.M. helped in writing and re-checking the paper, both technically and grammatically. All authors have read and agreed to the published version of the manuscript.

Funding: This research was funded by the National Research Foundation of Korea Grant funded by the Korean Government, grant number FRF-2019R1A2C2003636.

Institutional Review Board Statement: Not applicable.

Informed Consent Statement: Not applicable.

Acknowledgments: This research was supported by the National Research Foundation of Korea Grant funded by the Korean Government (FRF-2019R1A2C2003636).

Conflicts of Interest: The authors declare no conflict of interest.

\section{References}

1. Panthi, K.K. Evaluation of rock bursting phenomena in a tunnel in the Himalayas. Bull. Eng. Geol. Environ. 2012, 71, 761-769. [CrossRef]

2. Palmstrom, A.; Stille, H. Ground behaviour and rock engineering tools for underground excavations. Tunn. Undergr. Space Technol. 2007, 22, 363-376. [CrossRef]

3. Stille, H.; Palmström, A. Ground behaviour and rock mass composition in underground excavations. Tunn. Undergr. Space Technol. 2008, 23, 46-64. [CrossRef]

4. Sharma, H.; Tiwari, A. Tunnelling in the Himalayan Region: Geological problems and solutions. Int. Water Power Dam Constr. 2012, 64, 14-19.

5. Carter, T. Himalayan ground conditions challenge innovation for successful TBM Tunnelling. In Proceedings of the Invited Paper in Proc. Hydrovision India 2011 Conference, SESSION 5c:(Risk Management in Tunnelling); Golder Associates: Toronto, ON, Canada; 2011; p. 20.

6. Celada, B.; Tardáguila, I.; Varona, P.; Rodríguez, A.; Bieniawski, Z. Innovating tunnel design by an improved experience-based RMR system. In Proceedings of the World Tunnel Congress, Foz do Iguaçu, Brazil, 9-15 May 2014; p. 9. 
7. Verman, M.; Carter, T.; Babendererde, L. TBM vs D\&B-A difficult choice in mountain terrain-some geotechnical guidelines. In 12th ISRM Congress; International Society for Rock Mechanics: Lisbon, Portugal, 2011.

8. Rehman, H.; Ali, W.; Naji, A.; Kim, J.-J.; Abdullah, R.; Yoo, H.-K. Review of rock-mass rating and tunneling quality index systems for tunnel design: Development, refinement, application and limitation. Appl. Sci. 2018, 8, 1250. [CrossRef]

9. Mazaira, A.; Konicek, P. Intense rockburst impacts in deep underground construction and their prevention. Can. Geotech. J. 2015, 52, 1426-1439. [CrossRef]

10. Hanif, H.; Khurshid, M.B.; Lindhard, S.M.; Aslam, Z. Impact of variation orders on time and cost in mega hydropower projects of Pakistan. J. Constr. Dev. Ctries. 2016, 21, 37. [CrossRef]

11. Kizilbash, M.H.; Dickson, P.A.; Jaffery, N.A. Neelum Jhelum hydroelectric project: Pre-excavation grouting in twin headrace tunnels. Grouting 2017, 2017, 238-248.

12. Vestad, M. Analysis of the Deformation Behavior at the Underground Caverns of Neelum Jhelum HPP. Master's Thesis, Department of Geology and Mineral Resources Engineering, Norvegian University of Science and Technology, Trondheim, Norway, 2014.

13. DiPietro, J.A.; Pogue, K.R. Tectonostratigraphic subdivisions of the Himalaya: A view from the west. Tectonics 2004, 23. [CrossRef]

14. Magsi, H.Z. Seismogeodynamics of the Hazara-Kashmir transverse trough, Pakistan. New Concepts Glob. Tecton. J. 2015, 3, 4.

15. Ashcroft, B.; Peach, G.; Mierzejewski, J.; de Rivaz, B.; Yerlikaya, M. Design and construction of cast in-situ steel fibre reinforced concrete headrace tunnels for the Neelum Jhelum Hydroelectric project. In Tunnels and Underground Cities. Engineering and Innovation Meet Archaeology, Architecture and Art; CRC Press: Boca Raton, FL, USA, 2019; pp. 1667-1677.

16. Bilal, A.; Yasin, M.; Ali, A. The geology and structure of Neogene rocks in Dadyal and adjacent areas, in the sub-Himalayas, Azad Jammu and Kashmir, Pakistan. Earth Sci. Malays. 2017, 1, 15-20. [CrossRef]

17. Li, P.-X.; Feng, X.-T.; Feng, G.-L.; Xiao, Y.-X.; Chen, B.-R. Rockburst and microseismic characteristics around lithological interfaces under different excavation directions in deep tunnels. Eng. Geol. 2019, 260, 105209. [CrossRef]

18. Naji, A.M.; Emad, M.Z.; Rehman, H.; Yoo, H. Geological and geomechanical heterogeneity in deep hydropower tunnels: A rock burst failure case study. Tunn. Undergr. Space Technol. 2019, 84, 507-521. [CrossRef]

19. Hussain, A.; Yeats, R.S. Geological setting of the 8 October 2005 Kashmir earthquake. J. Seismol. 2009, 13, 315-325. [CrossRef]

20. Sharafat, A.; Tanoli, W.A.; Raptis, G.; Seo, J.W. Controlled blasting in underground construction: A case study of a tunnel plug demolition in the Neelum Jhelum hydroelectric project. Tunn. Undergr. Space Technol. 2019, 93, 103098. [CrossRef]

21. Naji, A.M.; Rehman, H.; Emad, M.Z.; Ahmad, S.; Kim, J.-J.; Yoo, H. Static and dynamic influence of the shear zone on rockburst occurrence in the headrace tunnel of the Neelum Jhelum hydropower project, Pakistan. Energies 2019, 12, 2124. [CrossRef]

22. Naji, A.; Rehman, H.; Emad, M.; Ahmed, S.; Kim, J.; Yoo, H. Rockburst evaluation in complex geological environment in deep hydropower tunnels. In Tunnels and Underground Cities. Engineering and Innovation Meet Archaeology, Architecture and Art; CRC Press: Boca Raton, FL, USA, 2019; pp. 1002-1009.

23. Ma, C.; Chen, W.; Tan, X.; Tian, H.; Yang, J.; Yu, J. Novel rockburst criterion based on the TBM tunnel construction of the Neelum-Jhelum (NJ) hydroelectric project in Pakistan. Tunn. Undergr. Space Technol. 2018, 81, 391-402. [CrossRef]

24. Yang, J.; Chen, W.; Zhao, W.; Tan, X.; Tian, H.; Yang, D.; Ma, C. Geohazards of tunnel excavation in interbedded layers under high in situ stress. Eng. Geol. 2017, 230, 11-22. [CrossRef]

25. Bawden, W. Neelum Jhelum hydroelectric project rockburst investigation report. Unpublished work. 2015.

26. Khan, A.K. Engineering of Headrace Tunnel For Neelum Jhelum Hydropower Project. Available online: https:/ / pecongress.org. pk/images/upload/books/1-Abdul\%20Khaliq\%20Khan.pdf (accessed on 10 March 2020).

27. Shang, Y.J. Geological conditions at site of '31st May' severe rockburst in TBM696. 2015. internal report.

28. Iqbal, M.S.; Hussain, I.; Saeed, U. Water pressure build-up in rock mass and associated field challenges at Neelum Jhelum hydroelectric project Pakistan. In Proceedings of the 15th International Conference on Geotechnical Engineering, Lahore, Pakistan, 5-7 December 2019.

29. Peach, G.; Ashcroft, B. Severe rockburst event-TBM Recovery-A case study. In Proceedings of the World Tunnel Congress, Dubai, United Arab Emirates, 21-26 April 2018.

30. Mierzejewski, J.; Ashcroft, G.B. Short-term rockburst prediction in tbm tunnels. In Proceedings of the World Tunnel Congress, Bergen, Norway, 9-15 June 2017; pp. 9-14.

31. Tian, H.; Chen, W.; Ma, C.; Yang, D.; Tan, X. Energy release analysis of a severe rockburst in a headrace tunnel crossing a tectonic stress zone. Shock Vib. 2019, 2019. [CrossRef]

32. Rehman, H.; Naji, A.M.; Kim, J.-J.; Yoo, H. Extension of tunneling quality index and rock mass rating systems for tunnel support design through back calculations in highly stressed jointed rock mass: An empirical approach based on tunneling data from Himalaya. Tunn. Undergr. Space Technol. 2019, 85, 29-42. [CrossRef]

33. Kondo, H.; Nakata, T.; Akhtar, S.S.; Wesnousky, S.G.; Sugito, N.; Kaneda, H.; Tsutsumi, H.; Khan, A.M.; Khattak, W.; Kausar, A.B. Long recurrence interval of faulting beyond the 2005 Kashmir earthquake around the northwestern margin of the Indo-Asian collision zone. Geology 2008, 36, 731-734. [CrossRef]

34. Gahalaut, V.K. Coulomb stress change due to 2005 Kashmir earthquake and implications for future seismic hazards. J. Seismol. 2009, 13, 379-386. [CrossRef]

35. Wang, C.; Bao, L. Predictive analysis of stress regime and possible squeezing deformation for super-long water conveyance tunnels in Pakistan. Int. J. Min. Sci. Technol. 2014, 24, 825-831. [CrossRef] 
36. Amici, R.; Peach, G.; Nadeem, M. TBM in Azad Kashmir region of Pakistan: In situ stress measurements for rockburst prevision. Geotech. Res. 2018, 6, 39-51. [CrossRef]

37. Amici, R.; Peach, G.; Nadeem, M. In-situ stress measurements in TBM tunnels prone to rockbursts. In Tunnels and Underground Cities. Engineering and Innovation Meet Archaeology, Architecture and Art; CRC Press: Boca Raton, FL, USA, 2019; pp. 597-606.

38. Naji, A.; Rehman, H.; Emad, M.; Yoo, H. Impact of shear zone on rockburst in the deep Neelum-Jehlum hydropower tunnel: A numerical modeling approach. Energies 2018, 11, 1935. [CrossRef]

39. Khan, M.S.; Tahir, S.; Gillani, A.; Khan, M.W. Evaluation of tunnel excavation methods for Neelum Jhelum hydro power project, Pakistan. J. Am. Sci. 2011, 7, 1232-1236.

40. Goel, R. Experiences and lessons from the use of TBM in the Himalaya-A review. Tunn. Undergr. Space Technol. 2016, 57, 277-283. [CrossRef]

41. Hung, C.J.; Monsees, J.; Munfah, N.; Wisniewski, J. Technical Manual for Design and Construction of Road Tunnels—Civil Elements; American Association of State Highway and Transportation Officials: Washington, DC, USA, 2009.

42. Ullah, I.; Peach, G.; Nadeem, M. Tunnel boring machine advance ground investigation in rockburst-prone ground conditions on Neelum Jhelum project. In International Congress and Exhibition "Sustainable Civil Infrastructures: Innovative Infrastructure Geotechnology"; Springer: Cham, Switzerland, 2017; pp. 53-75.

43. Ocak, I.; Bilgin, N. Comparative studies on the performance of a roadheader, impact hammer and drilling and blasting method in the excavation of metro station tunnels in Istanbul. Tunn. Undergr. Space Technol. 2010, 25, 181-187. [CrossRef]

44. Hoek, E.; Marinos, P. Tunnelling in overstressed rock. In Regional Symposium of the International Society for Rock Mechanics, EUROCK; International Society for Rock Mechanics and Rock Engineering: Lisbon, Portugal, 2009; pp. 49-60.

45. Haibo, L.; Xiang, X.; Jianchun, L.; Jian, Z.; Bo, L.; Yaqun, L. Rock damage control in bedrock blasting excavation for a nuclear power plant. Int. J. Rock Mech. Min. Sci. 2011, 48, 210-218. [CrossRef]

46. Zhang, C.; Feng, X.; Zhou, H.; Qiu, S.; Wu, W. A top pilot tunnel preconditioning method for the prevention of extremely intense rockbursts in deep tunnels excavated by TBMs. Rock Mech. Rock Eng. 2012, 45, 289-309. [CrossRef]

47. Girmscheid, G.; Schexnayder, C. Drill and blast tunneling practices. Pract. Period. Struct. Des. Constr. 2002, 7, 125-133. [CrossRef]

48. Ahmad, S.; Naji, A.M.; Hussain, I. Mechanized versus conventional tunnelling applied in challenging ground conditions-A statistical overview of NJ project Pakistan. In Proceedings of the 15th International Conference on Geotechnical Engineering, Lahore, Pakistan, 5-7 December 2019.

49. Amberg, F. Tunnelling in high overburden with reference to deep tunnels in Switzerland. In Proceedings of the 30th ITA-AITES World Tunnel Congress, Singapore, 22-27 May 2004.

50. Zhang, C.; Liu, N.; Chu, W. Key technologies and risk management of deep tunnel construction at Jinping II hydropower station. J. Rock Mech. Geotech. Eng. 2016, 8, 499-512. [CrossRef]

51. Ma, T.; Tang, C.; Tang, L.; Zhang, W.; Wang, L. Rockburst characteristics and microseismic monitoring of deep-buried tunnels for Jinping II Hydropower Station. Tunn. Undergr. Space Technol. 2015, 49, 345-368. [CrossRef]

52. Bhasin, R.; Grimstad, E. The use of stress-strength relationships in the assessment of tunnel stability. Tunn. Undergr. Space Technol. 1996, 11, 93-98. [CrossRef]

53. Barton, N. Deformation phenomena in jointed rock. Geotechnique 1986, 36, 147-167. [CrossRef]

54. Palmstrom, A. RMi-A Rock Mass Characterization System for Rock Engineering Purposes. Ph.D. Thesis, University of Oslo, Oslo, Norway, 1995.

55. Ortlepp, W.; Stacey, T. Rockburst mechanisms in tunnels and shafts. Tunn. Undergr. Space Technol. 1994, 9, 59-65. [CrossRef]

56. Hoek, E.; Carranza-Torres, C.; Corkum, B. Hoek-Brown failure criterion-2002 edition. Proc. NARMS-Tac 2002, 1, $267-273$.

57. Zhang, C.; Feng, X.-T.; Zhou, H.; Qiu, S.; Wu, W. Case histories of four extremely intense rockbursts in deep tunnels. Rock Mech. Rock Eng. 2012, 45, 275-288. [CrossRef]

58. Lee, C.; Sijing, W.; Zhifu, Y. Geotechnical aspects of rock tunnelling in China. Tunn. Undergr. Space Technol. 1996, 11, 445-454. [CrossRef]

59. Barton, N.; Lien, R.; Lunde, J. Engineering classification of rock masses for the design of tunnel support. Rock Mech. 1974, 6 , 189-236. [CrossRef]

60. Grimstad, E.; Barton, N. Updating the Q-system for NMT. In International Symposium on Sprayed Concrete-Modern Use of Wet Mix Sprayed Concrete for Underground Support, Fagemes, Oslo; Norwegian Concrete Association: Oslo, Norway, 1993.

61. Kirsten, H. Case histories of groundmass characterization for excavatability. In Rock Classification Systems for Engineering Purposes; ASTM International: West Conshohocken, PA, USA, 1988.

62. Chen, W.; Lu, S.; Guo, X.; Qiao, C. Research on unloading confining pressure tests and rockburst criterion based on energy theory. Chin. J. Rock Mech. Eng. 2009, 28, 1530-1540.

63. Huang, D.; Li, Y. Conversion of strain energy in triaxial unloading tests on marble. Int. J. Rock Mech. Min. Sci. 2014, 66, 160-168. [CrossRef]

64. Rehman, H.; Naji, A.; Ali, W.; Abdullah, R. Support design for the diversion tunnel of Diamer Basha Dam, Pakistan, considering the recent developments in empirical systems. In Proceedings of the GEOTROPIKA—ICHITRA, Kuala Lumpur, Malaysia, 27-28 February 2019.

65. Rehman, H.; Naji, A.M.; Ali, W.; Mukhta, H.M.; Mandokhail, S.U.J. Numerical evaluation of empirically suggested support system for the diversion tunnels at Diamer Basha Dam project, Pakistan. J. Himal. Earth Sci. 2019, 52, 1-13. 
66. Aydan, Ö.; Ulusay, R.; Tokashiki, N. A new rock mass quality rating system: Rock mass quality rating (RMQR) and its application to the estimation of geomechanical characteristics of rock masses. Rock Mech. Rock Eng. 2014, 47, 1255-1276. [CrossRef]

67. Yan-Jun, S.; Rui-Xin, Y.; Geng-She, Y.; Guang-Li, X.; Shan-Yong, W. Comparisons of evaluation factors and application effects of the new [BQ] GSI system with international rock mass classification systems. Geotech. Geol. Eng. 2017, 35, 2523-2548. [CrossRef]

68. Bieniawski, Z. Engineering classification of jointed rock masses. Civ. Eng. South. Afr. 1973, 15, 333-343.

69. Bieniawski, Z.T. Engineering Rock Mass Classifications: A Complete Manual for Engineers and Geologists in Mining, Civil, and Petroleum Engineering; John Wiley \& Sons: Hoboken, NJ, USA, 1989.

70. Rehman, H.; Naji, A.; Kim, J.-J.; Yoo, H.-K. Empirical evaluation of rock mass rating and tunneling quality index system for tunnel support design. Appl. Sci. 2018, 8, 782. [CrossRef]

71. Kim, H.; Rehman, H.; Ali, W.; Naji, A.M.; Kim, J.-J.; Kim, J.; Yoo, H. Classification of factors affecting the performance of fully grouted rock bolts with empirical classification systems. Appl. Sci. 2019, 9, 4781. [CrossRef]

72. Kim, J.; Rehman, H.; Ali, W.; Naji, A.M.; Yoo, H. Weightage effect during back-calculation of rock-mass quality from the installed tunnel support in rock-mass rating and tunneling quality index system. Appl. Sci. 2019, 9, 2065. [CrossRef]

73. Palmstrom, A.; Broch, E. Use and misuse of rock mass classification systems with particular reference to the Q-system. Tunn. Undergr. Space Technol. 2006, 21, 575-593. [CrossRef]

74. Rehman, H.; Kim, J.-J.; Yoo, H.-K. Stress reduction factor characterization for highly stressed jointed rock based on tunneling data from Pakistan. In World Congress on Advances in Structural Engineering and Mechanics; ASEM17: Seoul, Korea, 2017.

75. Lee, J.; Rehman, H.; Naji, A.; Kim, J.-J.; Yoo, H.-K. An empirical approach for tunnel support design through Q and RMi systems in fractured rock mass. Appl. Sci. 2018, 8, 2659. [CrossRef]

76. Lipponen, A.; Manninen, S.; Niini, H.; Rönkä, E. Effect of water and geological factors on the long-term stability of fracture zones in the Päijänne Tunnel, Finland: A case study. Int. J. Rock Mech. Min. Sci. 2005, 42, 3-12. [CrossRef]

77. Panthi, K.K. Analysis of Engineering Geological Uncertainties Related to Tunnelling in Himalayan Rock Mass Conditions. Ph.D. Thesis, Fakultet for Ingeniørvitenskap og Teknologi, Trondheim, Norway, 2006.

78. Ahmad, S.; Naji, A.M.; Hussain, I.; Rehman, H.; Yoo, H. Ground saturation response during first filling of lined pressure tunnels: A case study. Rock Mech. Rock Eng. 2020, 1-23. [CrossRef] 